\title{
Audiovisual fiction and tourism promotion: The impact of film and television on the image of tourist destinations and contributions from textual analysis
}

\author{
Jorge Nieto-Ferrando; Sebastián Sánchez-Castillo; Beatriz Gómez-Morales
}

Nota: Este artículo se puede leer en español en:

http://www.profesionaldelainformacion.com/contenidos/2021/nov/nieto-sanchez-gomez_es.pdf

How to cite this article:

Nieto-Ferrando, Jorge; Sánchez-Castillo, Sebastián; Gómez-Morales, Beatriz (2021). “Audiovisual fiction and tourism promotion: the impact of film and television on the image of tourist destinations and contributions from textual analysis". Profesional de la información, v. 30, n. 6, e300614.

https://doi.org/10.3145/epi.2021.nov.14

Article received on June $7^{\text {th }} 2021$ Approved on November $3^{\text {rd }} 2021$

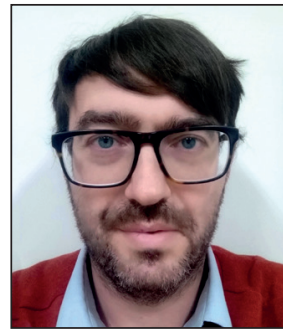

Jorge Nieto-Ferrando $\square$

https://orcid.org/0000-0003-3075-2636

Universitat de Lleida

Departament de Filologia Catalana i

Comunicació

$\mathrm{PI}$. de Víctor Siurana, 1

25003 Lleida, Spain

jorge.nieto@udl.cat

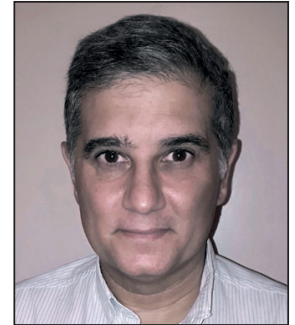

Sebastián Sánchez-Castillo

https://orcid.org/0000-0003-3751-6425

Universitat de València

Departamento de Teoría de los Lenguajes

y Ciencias de la Comunicación

Av. Blasco Ibáñez, 32

46010 Valencia, Spain

sebastian.sanchez@uv.es

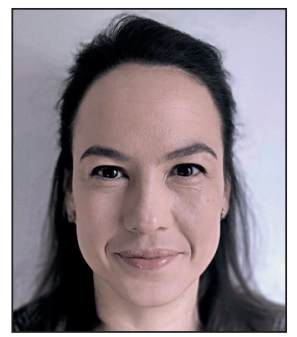

\section{Beatriz Gómez-Morales}

https://orcid.org/0000-0002-0557-528X

Universitat de Lleida

Departament de Filologia Catalana i

Comunicació

PI. de Víctor Siurana, 1

25003 Lleida, Spain

beatriz.gomez@udl.cat

\begin{abstract}
The first studies of film and television as inducers of tourism appeared in the 1990s. In light of the role these media play in tourist decisions, studies of the capacity of audiovisual fiction to project a unique image of tourist attractions and destinations or to influence audience perceptions of them are particularly important. However, ever since research of this kind began, it has suffered from significant theoretical and methodological shortcomings associated mainly with the lack of an interdisciplinary approach. Most of the research has been in the field of tourism and marketing studies, with only a limited number of contributions from film and television studies. The objective of this article is to offer a critical review of studies exploring the relationship between audiovisual fiction and tourist destination image. The aim is to identify their conceptual shortcomings and to point out possible solutions with reference to audiovisual textual theory and analysis. The article begins with the identification of the main areas studied in this research: the effect on the attributes of tourist destinations and on their overall image, stereotypes, and the capacity of audiovisual fiction to vest the locations where their stories are set with different connotations. This is followed by an analysis of studies that exhibit more of an interdisciplinary approach by combining audiovisual studies and tourism studies. The article then addresses the debate over the types of audiovisual productions that researchers argue have the greatest tourism-inducing capacity. Finally, the conclusions point out possible future lines of research based more on explanation than on description, recommending the systematic incorporation of textual analysis into research on film-induced tourism, and particularly on its impact on tourist destination image.
\end{abstract}




\section{Keywords}

Audiovisual fiction; Tourist promotion; Tourism; Image-induced tourism; Film-induced tourism; Perceived tourist destination image; Cinema; TV; Image of the destinations; Images; Textual analysis; Projected tourist destination image; Stereotypes; Audiovisual textual analysis; Destination placement; Marketing; Effects of fiction.

\section{Funding}

This article is a result of the $\mathrm{R}+\mathrm{D}+\mathrm{i}$ project PID2020-112668GB-I00, funded by the Spanish Ministry of Science and Innovation and the State Research Agency: MCIN/AEI/10.13039/501100011033.

\section{Introduction}

Since the 1990s, studies of film- and television-induced tourism have been examining the relationship between the places where films and series are filmed or set and tourism to those locations. Notable among these are studies focusing on the potential for audiovisual productions to promote tourist destinations, to help shape their image and, in general, to influence the whole decision-making process that leads tourists to choose to visit them (Beeton, 2016; Bolan; Williams, 2008; Cardoso et al., 2017; Connell, 2012). The implications of this research for the tourism and audiovisual industries are significant. The tourism-inducing capacity of films and television series can contribute to more balanced tourist flows, particularly to the benefit of lesser-known destinations, although it can also lead to tourism management problems at such destinations when they lack the infrastructure to welcome large numbers of tourists. At the same time, the diverse range of tourist attractions suitable for use as filming locations can provide a boost to local audiovisual industries.

However, despite its obviously interdisciplinary nature, research conducted in this area has not often drawn on studies of film and television (Connell, 2012) or of the effects of mass media (Fernández-Young; Young, 2008; Kim; Long; Robinson, 2009; Kim, 2012). Changes to the perceptions of a destination's attributes after viewing a film are described without considering the fact that these effects are produced, at least in part, within the audiovisual text itself. There are also experimental studies that suffer from significant methodological errors, as they measure the impact on destination attributes after playing only a few fragments of a film to a group of spectators, when audiovisual productions are units made up of closely interconnected elements. The narrative space where tourist attractions and destinations are represented has a meaning of its own and in the context of the narrative as a whole. Moreover, spectators participate actively in the reception process by forming expectations about what will happen based on the information they receive. And these expectations may be either modified or confirmed by new information (Bordwell, 1990; Carroll, 2001; Chatman, 1990; Vale, 1996). This is why it is impossible to measure the effects of an audiovisual production without studying the production as a whole or taking into account the fragmentation inherent in the text itself (in the case of seasons in television fiction).

Failing to consider studies of media effects results in a uniform conception of audiences and audience behaviour that ignores their sociocultural diversity, their different levels of audiovisual media consumption, and the complex relationships they develop with audiovisual texts. It has also led to overestimations of the effect of an audiovisual production on audiences, positing simplistic causal relationships between the presence of a tourist attraction in the production and an increase in the number of visitors the attraction receives. Busby \& Klug (2001), Croy (2010), Macionis, \& Sparks (2009), Di-Cesare, D’Angelo, \& Rech (2009), and Fernández-Young \& Young (2008) all provide evidence that only slightly more than $5 \%$ of tourists who visit a destination are motivated to do so because of its appearance in a film or TV series. Conversely, Hudson \& Ritchie (2006b) present the results of a survey conducted in 2004 that concluded that $80 \%$ of Britons considered holidaying at a tourist destination based on its presence in a film. The stark difference between these two figures highlights the need to break down the complex process leading up to the tourist experience in order to measure the effect of the audiovisual production at each moment (Di-Cesare; D’Angelo; Rech, 2009). In simple terms, the steps in this process can be described as follows:

1) Awareness of the existence of a place to visit after viewing the audiovisual production (Croy, 2010; Tooke; Baker, 1996).

2) Desire to travel to the destination (Di-Cesare; D’Angelo; Rech, 2009).

3) Search for information about the location (the audiovisual production is itself a source of information on the destination, while also inspiring searches for information in other media).

4) Destination image.

5) Attitude towards the destination (Quintal; Phau, 2015).

6) Motivation to visit: both the influence of audiovisual productions on usual tourist motivations and motivations arising specifically from those productions (Macionis; Sparks, 2009; Michael et al., 2020; Oviedo-García et al., 2016; Reijnders, 2016).

7) Intention to visit (Riley; Baker; Van-Doren, 1998).

8) The visit itself. 
According to Fernández-Young \& Young (2008), the effects of audiovisual fiction can be vague or indirect. An example of this is advertising for a destination that makes use of photographs of successful productions filmed there or of the feedback of tourists who recommend the destination to other potential tourists with reference to its association with a film or series.

This study focuses on research into the relationship between audiovisual fiction and destination image. The academic literature distinguishes between a destination's projected image and its perceived image. Between these two there may be overlaps, negotiations, and contradictions (Mercille, 2005). Mercille (2005) and Almeida-Santos \& Buzinde (2007) use the term "representation" for projected image. According to the traditional differentiation established by Gartner (1993), projected image is considered induced when it comes from advertising and therefore originates with the destination's promoters. Its objective is to create a differentiated perception of the destination among specific target audiences. But projected image can also be autonomous when it is not promotional and does not originate with the destination itself. This type of projected image, as it is not considered induced, is more credible and has a bigger influence on perceived image. Gartner (1993) argues that audiovisual fiction projects this type of autonomous images.

Perceived image is the set of impressions that audiences have of a destination based on all of the beliefs, ideas, expectations and feelings it elicits (Baloglu; McCleary, 1999; Gallarza; Gil-Saura; Calderón, 2002). Perceived image consists of cognitive, affective and connotative components. The cognitive component of the image is linked to beliefs about the destination and its attributes, the affective is related to the emotional responses it elicits (Beerli; Martín, 2004; Gartner, 1993; Kim; Richardson, 2003; Macionis, 2004), and the connotative is associated with the behaviours it provokes. Perceived image is essential to the tourist decision-making process (Baloglu; McCleary, 1999; Echtner; Ritchie, 1991; Fakeye; Crompton, 1991), as that process depends more on impressions than on "objective realities" (Beerli; Martín, 2004).

The objective of this study is to identify gaps in the research on the impact of audiovisual fiction on tourist destination image and to offer some suggestions for how to fill them. Many of these gaps relate to the lack of communication between tourism studies and film and television studies, which is why the first suggestion this study offers relates to the need for a closer relationship between these two fields.

This study is divided into three parts:

1) A brief literature review (Section 3). The purpose of this section is to categorise studies based on their objectives and research topics, on whether they connect their analysis of the impact of audiovisual productions on destination image to other aspects of the destination selection process, and on whether they draw on audiovisual textual theory and analysis.

2) A critical conceptual analysis of the research (Section 4). The purpose of this section is to identify both the advances and the gaps in the studies analysed, the debates they have generated, and how audiovisual theory and analysis can help further the research.

3) Conclusions (Section 5), along with suggestions for possible future lines of research underpinned by greater interaction between tourism studies and film and television studies.

It is important to stress that this study is not an exclusively descriptive review. The first and second parts of the article are oriented towards the identification of new approaches that could support further development of research on the relationship between audiovisual fiction and tourism.

\section{Method}

With the above in mind, the first part of this study (Section 3) offers an overview of the research based on references (articles in academic journals published in English) contained in Web of Science, published between 1990 and 2021, regardless of their impact. The search terms used were "film-induced tourism", "movie-induced tourism", "TV-induced tourism", "popular media-induced tourism", "film tourism", "movie tourism" and "TV tourism". These terms are generally the ones used in the literature: film-induced tourism, film tourism (Beeton, 2016), movie-induced tourism (Riley; Baker; Van-Doren, 1998), and TV-induced tourism (Su et al., 2011). The texts selected explore the impact of audiovisual fiction on destination image, either as the sole research topic or as part of the decision-making process that leads to the choice to visit a particular destination.

After a preliminary review of the articles, in the interests of ensuring a more systematic approach, the following categories were established:

1) Projected image (representation)

1.1) Overall positive projected image

1.2) Overall negative projected image

1.3) Projected stereotypes

1.4) Associated meanings

2) Perceived image (effects)

2.1) Overall positive perceived image

2.2) Overall negative perceived image

2.3) Positive changes to attributes

2.4) Negative changes to attributes

2.5) Perceived stereotypes 
3) Images, motivations, intentions to visit, and visits

4) Audiovisual theory and analysis

4.1) Limited theory and analysis

4.2) Advanced theory and analysis

The first two categories ( 1 and 2 ) refer to the research objectives and topics explored in the articles. The first category includes articles focusing on the representation of a tourist destination or attraction in audiovisual fiction. This category is subdivided into positive and negative projected images in the storylines of the productions (1.1 and 1.2), stereotypes associated with the locations that they make use of (1.3), and associated meanings (1.4). Associated meanings are the connotations acquired by the tourist attractions represented due to their relationship with other elements of the story and have nothing do with the attraction's natural features.

The second category includes studies focusing on the effects of audiovisual fiction on perceived image. A distinction is made between overall image and attributes (2.1-2.4) because many articles break down the image into different cognitive and affective attributes and analyse the effect of audiovisual productions on one of them. Subcategory 2.5 includes studies that analyse the effects on the audience of projected stereotypes associated with the destinations. No studies exploring the effects of associated meanings were identified.

The third category identifies articles that analyse the impact of audiovisual fiction on the image within the broader process leading to a choice of and visit to a destination. Finally, the fourth category covers articles that make use of audiovisual textual theory or analysis. Audiovisual textual analysis refers to breaking down audiovisual texts with the objective of describing their constituent elements in terms of both expression and content, their function, and the relationship between text and receiver (Casetti; Di-Chio, 1991). Some studies display a degree of interest in the analysis of audiovisual texts (4.1), while others demonstrate a more advanced understanding of the approach and include explicit references to other studies in this field (4.2).

Also analysed are co-occurrences of multiple categories (as these facilitate the identification of certain research gaps) and the nature of the use of audiovisual productions in the research. On this last point, three aspects are considered: 1) whether they study television series or films; 2 ) whether the results are based on case studies (one or two films or series) or on a corpus of audiovisual productions selected according to rigorous criteria; and 3) the method used to measure the effect on the audience of viewing the films or series.

The second part of this study (Section 4) offers a critical review of the main contributions of the sample. In general terms, it is structured the same way as the first section. However, to clarify exposure and identify the findings, gaps and debates, the categories have been divided into subcategories. A subsection (4.3) is also included that discusses the types of destinations more likely to be the object of film- or television-induced tourism and the types of audiovisual productions with the biggest tourism-inducing capacity. The critical conceptual analysis draws on key sources in the field of audiovisual textual analysis and on studies which, although they focus on different aspects of film- and television-induced tourism, present conceptual frameworks, results or conclusions of relevance to this review.

\section{Literature review}

A search in Web of Science, once it was verified that the content corresponded to the search terms, identified 487 articles, 55 of which focus specifically on the impact of audiovisual fiction on tourist destination image.

Of these 55, the largest proportion of articles (25) deal with perceived image, while another 17 focus on projected image. The relationship between the two appears in only 13 articles. A total of 16 articles explore positive projected image, while nine deal with negative projected image, of which there are three (Beeton, 2004; Mercille, 2005; Mestre; Del-Rey; Stanishevski, 2008) that analyse negative image together with positive image. In the case of perceived image, only seven studies describe negative changes to the perception of destination attributes or overall image due to the audiovisual production. Moreover, nearly all the articles deal with cases where films or television series have a significant impact on tourist destination image. Pan \& Tsang (2014) are the only scholars who analyse a case where tourist attraction placement has failed to have the desired positive effect.

The co-occurrence analysis (Table 2) revealed that there are only two articles classified in just a single category: Tzanelli (2003) (1.3) and Dung \& Reijnders (2013) (2.1). All the other articles fall into two or more categories. In general, a high level of co-occurrence was found among the subcategories within each of the categories of projected image and perceived image. However, co-occurrence across these two categories is very limited. Exceptions are the relationship between overall positive projected image and overall positive perceived image $(1.1,2.1)$ and projected stereotypes and perceived stereotypes $(1.3,2.5)$. This disconnect between projection and perception hinders the identification of dissonances. For example, there is no analysis of the possibility that an overall positive projected image in a production might generate a negative perceived image. Only a few studies point to this possibility when they relate audiovisual productions to other media texts (Nanjangud \& Reijnders, 2020; Ozretic-Dosen et al., 2018; Ertz et al., 2020).

With the exception of articles dealing with stereotypes $(1.3,2.5)$ and those that draw extensively on audiovisual theory and analysis (4.2), most studies relate the impact of audiovisual fiction on destination image to tourist motivations, 
Table 1. Research categories

1. Projected image (representation)

1.1. Overall positive projected image

Beeton (2004), Bencivenga, Chiarullo, \& Colangelo (2015), Croy (2010), Frost (2006), Frost (2010), Iwashita (2006), Iwashita (2008), Leotta (2009), Leotta (2020), López, Santomil-Mosquera, \& Lois-González (2015), Luo et al. (2014), Mercille (2005), Mestre, Del-Rey, \& Stanishevski (2008), Nieto-Ferrando (2020), Pan \& Tsang (2014), Urso (2015)

1.2. Overall negative projected image

Beeton (2004), D’Alessandro, Sommella, \& Vigagnoni (2015), Itoo \& Nagar (2017), Leotta (2020), Mercille (2005), Mestre, Del-Rey, \& Stanishevski (2008), Pratt (2015), Privitera (2015), Yang et al. (2017)

1.3. Projected stereotypes Beeton (2004), Bencivenga et al. (2015), Cordeiro (2011), D’Alessandro, Sommella, \& Vigagnoni (2015), Gkritzali, Lampel, \& Wiertz (2016), Iwashita (2006), Iwashita (2008), Justus, Kieti, \& Nthiga (2018), Mestre, Del-Rey, \& Stanishevski (2008), Nieto-Ferrando (2020), Prieto-Arranz \& Casey (2014), Reijnders (2009), Tzanelli (2003), Urso (2015)

1.4. Associated meanings Beeton (2004), Bencivenga, Chiarullo, \& Colangelo (2015), Busby \& Haines (2013), Croy (2010), Gkritzali, Lampel, \& Wiertz (2016), Hao \& Ryan (2013), Iwashita (2008), Leotta (2009), Nieto-Ferrando (2020), Privitera (2015), Reijnders (2009), Riley et al. (1998), Urso (2015)

2. Perceived image (effects)

Bencivenga, Chiarullo, \& Colangelo (2015), Chan (2007), Croy (2010), Dung \& Reijnders (2013), Ertz et al. (2020), Hahm \& Wang (2011), Huang (2013), Itoo \& Nagar (2017), Iwashita (2006), Iwashita (2008), Josiam et al. (2014), Mercille (2005), Nanjangud \& Reijnders (2020), O'Connor Flanagan, \& Gilbert (2008), Ozretic-Dosen et al. (2018), Pan \& Tsang (2014), Rodríguez-Campo, Fraiz-Brea, \& Rodríguez-Toubes-Muñiz (2011), Shani et al. (2009), Spears et al. (2013), St-James, Darveau, \& Fortin (2018), Su et al. (2011), Wen et al. (2018)

2.2. Overall negative perceived image D’Alessandro, Sommella, \& Vigagnoni (2015), Pratt (2015), Shani et al. (2009)

Chan (2007), Croy (2010), Di-Cesare, D’Angelo, \& Rech (2009), Ertz et al. (2020), Gkritzali, Lampel, \& Wiertz (2016), Hahm, Upchurch, \& Wang (2008), Hahm \& Wang (2011), Hudson, Wang, \& Moreno-Gil (2011), Josiam et al. (2014), Kim \& Richardson (2003), Peters et al. (2011), Quintal

2.3. Positive changes to attributes \& Phau (2015), Rodríguez-Campo, Fraiz-Brea, \& Rodríguez-Toubes-Muñiz (2011), Shani et al. (2009), Soliman (2011), Suhud \& Willson (2018), Wen et al. (2018), Yang et al. (2017), Zeng et al. (2015)

2.4. Negative changes to attributes Correira-Loureiro \& Araujo (2015), Hahm \& Wang (2011), Hudson, Wang, \& Moreno-Gil (2011), Kim \& Richardson (2003), Shani et al. (2009)

Bencivenga, Chiarullo, \& Colangelo (2015), Iwashita (2006), Iwashita (2008), Josiam et al.

2.5. Perceived stereotypes (2014), Justus, Kieti, \& Nthiga (2018)

3. Images, motivations, intentions and visits

Bencivenga, Chiarullo, \& Colangelo (2015), Chan (2007), Correira-Loureiro \& Araujo (2015), Croy (2010), D’Alessandro, Sommella, \& Vigagnoni (2015), Di-Cesare, D’Angelo, \& Rech (2009), Frost (2006), Frost (2010), Hahm, Upchurch, \& Wang (2008), Hahm \& Wang (2011), Huang (2013), Itoo \& Nagar (2017), Iwashita (2008), Josiam et al. (2014), Kim \& Richardson (2003), Leotta (2020), López, Santomil-Mosquera, \& Lois-González (2015), Nanjangud \& Reijnders (2020), Nieto-Ferrando (2020), Pan \& Tsang (2014), Pratt (2015), Privitera (2015), Quintal \& Phau (2015), Reijnders (2009), Riley et al. (1998), Shani et al. (2009), Soliman (2011), Spears et al. (2013), St-James, Darveau, \& Fortin (2018), Su et al. (2011), Yang, Vanden-Bergh, \& Lee (2017), Wen et al. (2018)

4. Audiovisual theory and analysis

4.1. Limited theory and analysis Cordeiro (2011), Frost (2006), Frost (2010), Hao \& Ryan (2013), Huang (2013), Iwashita (2006), Kim \& Richardson (2003), Pan \& Tsang (2014), Shani et al. (2009), Su et al. (2011), Yang, Vanden-Bergh, \& Lee (2017)

4.2. Advanced theory and analysis Leotta (2009), Leotta (2020), Luo et al. (2014), Mestre, Del-Rey, \& Stanishevski (2008), Nieto-Ferrando (2020), Reijnders (2009)

intentions, or visits (3). However, this relationship is not explored systematically, as the studies focus on destination image, including the occasional comment about its impact on motivations or on the number of visitors to the locations in question.

Most articles studying "projected stereotypes" also deal with "overall positive projected image" and "associated meanings", while those analysing "perceived stereotypes" also focus on "overall positive perceived image" and "projected stereotypes". Only three studies connect "projected stereotypes" to "overall negative projected image" (Beeton, 2004; D’Alessandro; Sommella; Vigagnoni, 2015; Mestre; Del-Rey; Stanishevski, 2008), one of which also connects it to "overall negative perceived image" (D’Alessandro; Sommella; Vigagnoni, 2015). None of the studies relate "perceived stereotypes" to negative projected or perceived images $(1.2,2.2,2.4)$. These findings constitute evidence of a lack of a critical perspective. One exception is the article by Tzanelli (2003) about the Orientalist image of Cephalonia projected in film, although it does not offer a positive or negative assessment of that image or of its effects.

The co-occurrence analysis also confirmed that very few studies draw on audiovisual theory and analysis. There are 11 articles containing a few very limited references, either from the perspective of narration or reception, and only 
Table 2. Co-occurrence across categories

\begin{tabular}{|c|c|c|c|c|c|c|c|c|c|c|c|c|}
\hline & 1.1. & 1.2 & 1.3. & 1.4 & 2.1 . & 2.2 & 2.3. & 2.4 . & 2.5 . & 3. & 4.1. & 4.2. \\
\hline $\begin{array}{l}\text { 1.1. Overall positive projected image } \\
(\mathrm{Gr}=16)\end{array}$ & & 4 & 7 & 7 & 6 & & 1 & & 3 & 9 & 4 & 5 \\
\hline $\begin{array}{l}\text { 1.2. Overall negative projected } \\
\text { image }(\mathrm{Gr}=9)\end{array}$ & 4 & & 3 & 2 & 2 & 2 & 1 & & & 6 & 1 & 2 \\
\hline $\begin{array}{l}\text { 1.3. Projected stereotypes } \\
(\mathrm{Gr}=14)\end{array}$ & 7 & 3 & & 7 & 3 & 1 & 1 & & 4 & 5 & 2 & 3 \\
\hline $\begin{array}{l}\text { 1.4. Associated meanings } \\
(\mathrm{Gr}=13)\end{array}$ & 7 & 2 & 7 & & 3 & & 2 & & 2 & 7 & 1 & 3 \\
\hline $\begin{array}{l}\text { 2.1. Overall positive perceived image } \\
(\mathrm{Gr}=22)\end{array}$ & 6 & 2 & 3 & 3 & & 1 & 8 & 2 & 4 & 15 & 5 & \\
\hline $\begin{array}{l}\text { 2.2. Overall negative perceived } \\
\text { image }(\mathrm{Gr}=3)\end{array}$ & & 2 & 1 & & 1 & & 1 & 1 & & 3 & 1 & \\
\hline $\begin{array}{l}\text { 2.3. Positive changes to attributes } \\
(\mathrm{Gr}=19)\end{array}$ & 1 & 1 & 1 & 2 & 8 & 1 & & 4 & 1 & 12 & 3 & \\
\hline $\begin{array}{l}\text { 2.4. Negative changes to attributes } \\
(\mathrm{Gr}=5)\end{array}$ & & & & & 2 & 1 & 4 & & & 4 & 2 & \\
\hline 2.5. Perceived stereotypes $(\mathrm{Gr}=5)$ & 3 & & 4 & 2 & 4 & & 1 & & & 3 & 1 & \\
\hline $\begin{array}{l}\text { 3. Images, motivations, intentions } \\
\text { and visits }(\mathrm{Gr}=32)\end{array}$ & 9 & 6 & 5 & 7 & 15 & 3 & 12 & 4 & 3 & & 8 & 3 \\
\hline $\begin{array}{l}\text { 4.1. Limited theory and analysis } \\
(\mathrm{Gr}=11)\end{array}$ & 4 & 1 & 2 & 1 & 5 & 1 & 3 & 2 & 1 & 8 & & \\
\hline $\begin{array}{l}\text { 4.2. Advanced theory and analysis } \\
(\mathrm{Gr}=6)\end{array}$ & 5 & 2 & 3 & 3 & & & & & & 3 & & \\
\hline
\end{tabular}

six of these demonstrate an in-depth understanding of the workings of audiovisual texts. These six studies all focus on projected image, while none analyse perceived image. It is significant that all the articles that draw on textual theory and analysis attempt to go beyond a description of content or effects to take an explanatory approach, in an effort to establish how and why audiovisual fiction influences destination image.

The general lack of attention to audiovisual theory and analysis, particularly in relation to effects, contrasts with advances in other areas of the analysis of film- and television-induced tourism. This is the case of studies of effects on tourism motivations and intentions to visit, as evidenced by Kim \& Kim (2018). The theoretical frameworks of these studies can be applied to the analysis of the effect of audiovisual productions on destination image.

An analysis of the evolution of the research over time reveals an increasing interest in the subject following the pioneering study by Riley, Baker, \& Van-Doren (1998), and particularly since 2005. A total of 12 articles were published between 2006 and 2010, 26 between 2011 and 2015, and 12 between 2016 and 2020. Prior to 2005, only five articles were published. In relation to the research categories shown in Table 1, no significant differences over time could be identified. No category is especially predominant in any five-year period. However, among the more recent studies, particularly among articles published in high-impact journals, there are literature reviews that are much more developed due to the accumulation of research.

In terms of the types of productions analysed, studies of films (37) clearly predominate over television series (9). There are also nine articles that deal with both, although most of these do so from the perspective of cinema. This imbalance is surprising given the large audience for television fiction and its technological development over the past twenty years, which has placed it on a par with the big screen.

Most of the articles are case studies focusing on one or a few audiovisual productions. When they go further, they explore genres related to a specific country, such as Turkish soap operas (Ozretic-Dosen et al., 2018) or Korean soap operas (Chan, 2007; Su et al., 2011; Zeng et al., 2015), or very generally to Bollywood films (Nanjangud; Reijnders, 2020) or Hollywood productions (Spears et al., 2013), or they examine a corpus of films to offer anecdotal evidence of their impact on tourism (Riley, Baker, \& Van-Doren, 1998). Exceptions are the studies by Frost (2010), focusing on the analysis of a corpus of films set in the Australian outback, and by Gkritzali, Lampel, \& Wiertz (2016) on the representation of Paris in Hollywood cinema. Other quite exhaustive and consistent corpora of audiovisual productions associated with specific destinations have been identified, such as Yorkshire (O’Connor; Flanagan; Gilbert, 2008) or Spain's Camino de Santiago (López; Santomil-Mosquera; Lois-González, 2015), although the research in these cases hardly focuses at all on the locations.

Finally, some of the studies of the effects of audiovisual fiction on tourist destination image (8 out of 25 articles) base their findings on convenience sampling (surveys or interviews with university students at the researchers' institutions after playing them a film). Some researchers attempt to justify this approach by suggesting that their objective is to analyse 
the impact of audiovisual fiction on perceptions of destinations among millennials (Hahm; Upchurch; Wang, 2008). The other articles on effects also make use of surveys, but of tourists visiting the locations, fans of the series or films studied, or members of tourist associations.

\section{Critical conceptual review}

\subsection{Effects and projections of destination image}

Audiovisual fiction can change the perception of a tourist destination's attributes and overall image, reinforce pre-existing stereotypes or construct new images based on the representation of tourist attractions in films or series.

\subsubsection{Positive and negative effects on overall destination image and attributes}

Some of the studies reviewed analyse positive or negative changes to the overall image of tourist destinations or to some of their attributes after viewing audiovisual productions. Some studies also explore disparities between image and visit or the interaction between audiovisual fiction productions and other media texts related to the destination.

\subsubsection{Overall image and attributes}

Changes caused by audiovisual fiction can affect the overall destination image, but its impact on individual destination attributes is more significant (Kim; Richardson, 2003; Hahm; Wang, 2011; Hudson; Wang; Moreno-Gil, 2011; Shani et al., 2009; Zeng et al., 2015). Researchers have broken destination image down into different cognitive and affective attributes in the interests of a more effective analysis of tourist perceptions. There are many categorisations of these attributes. Focusing on cognitive attributes, Echtner \& Ritchie (1991), for example, establish a scale that ranges from physical ("scenery/natural attractions", "climate", "tourist activities", etc.) to abstract ("opportunity for adventure", "opportunity to increase knowledge", "quality of service", etc.).

Using this classification, Hudson, Wang, \& Moreno-Gil (2011) discovered that watching The motorcycle diaries (Walter Salles, 2004) produced positive changes to perceptions of some attributes of Latin America (e.g. "nature" and "adventure"), and negative changes to others (e.g. "comfort" and "safety"). This is due to the film's presentation of poverty and social injustice in South America, but also to its showcasing of the continent's spectacular natural scenery (Shani et al., 2009). According to Correira-Loureiro \& De-Araujo (2015), a balance between negative and positive aspects of stories or the settings where they take place helps mitigate negative effects on the image. These authors conclude that City of God (Cidade de Deus, Fernando Meirelles, 2002) has had a negative influence on Rio de Janeiro's image by depicting violence as a social problem in Brazil without balancing this depiction with scenes showing the city's attractions.

\subsubsection{Negative storylines, media exposure and visits}

The literature is characterised by a debate over whether audiovisual productions that have "negative storylines", explore controversial topics or highlight violence have a negative impact on perceived image.

Researchers do not generally define what they mean by "negative storylines". From the perspective of film narratology, Bremond (1982) argues that each event in a film's plot can have a positive or negative outcome for the characters. In classical narration, these outcomes are combined over the course of the story. The climax, the protagonist's final struggle to achieve his or her goal, may also have a positive, negative, or mixed outcome. Authors like Chatman (1990) and Vanoye (1996) suggest that the effects of the various twists of fate faced by the characters can vary greatly. It is thus difficult to establish a causal connection between the outcome of an event and the perception of the setting in which it takes place. In fact, a negative outcome in a drama that is closely associated with a specific location may elicit sympathy for the characters from the spectator, and this feeling may enhance the location's image.

Along these lines, Yang, Vanden-Bergh, \& Lee (2017) argue that while the level of audience engagement with the story is important, there is no difference between violent and non-violent films in terms of their effects on destination image. The authors come to this conclusion based on their analysis of the impact on Tokyo's image of the two instalments of Kill Bill (Quentin Tarantino, 2003 and 2004) and the film Lost in translation (Sofia Coppola, 2003). But it is a different matter when violent events or negative storylines are associated with the reality of the place where they are set, either because they are based on a true story or because they depict realistic events, as in the case of City of God. In such cases, violent or bleak storylines can increase the negative effect on the image.

Moreover, because only a limited number of audiovisual productions set in Rio de Janeiro reach Europe or the United States, the effect of a film like City of God on the city's projected image will be much more intense for European and American audiences. A large number of films and series set in a location, as well as their diversity in terms of genres, can compensate for one production dealing with a controversial topic.

The level of media exposure of the destination and the meaning of the image projected are also essential factors to consider when measuring the impact of a film or

It is significant that all the articles that draw on textual theory and analysis attempt to go beyond a description of content or effects to take an explanatory approach, in an effort to establish how and why audiovisual fiction influences destination image 
a series on its image. A positive image projected by audiovisual fiction productions can compensate for negative images projected by news media, but the latter may also eclipse the effect of the former (Nanjangud \& Reijnders, 2020; Ozretic-Dosen et al., 2018; Ertz et al., 2020).

However, a production that deals with negative topics that are closely associated with the location where its story takes place does not necessarily discourage tourism, as Pratt (2015) demonstrates. D’Alessandro, Sommella, \& Vigagnoni (2015) analyse the case of Naples. In the 1990s, audiovisual fiction became an essential factor in the enhancement of the city's image, which has always been compromised by problems of corruption and organised crime. According to this study, the success of Roberto Saviano's novel Gomorra (2006), based on real events, and its subsequent adaptation as a film (Matteo Garrone, 2008) and a television series (Cattleya, Fandango \& Sky, 2014-) have undone much of the work done to improve the city's image. However, Gomorra may also have had a positive impact on dark tourism, as Leotta (2020) suggests that a marked increase in visitors to the city was identified in 2014, coinciding with the release of the first season of the series.

\subsubsection{Image and stereotypes}

Some of the studies reviewed explore the relationship between stereotypes, audiovisual fiction and destination image. Stereotypes are simplistic notions shared by a group that help them to understand, organise and categorise a reality until a more detailed exploration of that reality or a direct experience with it enables them to move beyond them -although this does not always happen. As suggested by Hall (1997), they also have the effect of reducing, essentialising, naturalising and pigeonholing people or places. The simplification inherent in stereotyping can influence the perceived image of a destination (Andsager; Drzewiecka, 2002; Rein; Kotler; Haider, 1993). Many of the projected and perceived stereotypes of tourist destinations can be traced back to $19^{\text {th }}$-century Romanticism (Miossec, 1977).

The workings of audiovisual fiction can help reinforce stereotypes associated with tourist destinations. These simplistic shared notions are essential for the cooperation that every audiovisual storyline demands of the spectator (Bordwell, 1990). They facilitate the spectator's successful transformation of the limited materials of the narrative into a coherent story. Stereotypes, serving as a foundation to draw on, can reduce the time needed in the narrative to develop characters or settings, as such simplifications convey all the necessary information about their characteristics. The use of stereotypes in audiovisual storytelling requires the spectator to apply them in order to understand and interpret the story. In this way, the stereotype is reinforced and disseminated.

\subsubsection{Stereotypes and expectations}

Some studies explore the relationship between stereotypes and tourist expectations. Iwashita (2006) studies stereotypes of "Britishness" and their importance for projecting a recognisable image of Britain in period films, televisions series and literature. Although perceived image is an individual construction influenced by various factors, the author considers the stereotype to be an element of the image shared by the group that renders the destination familiar -a view shared by Andsager \& Drzewiecka (2002).

Iwashita points out that Britain's own productions make use of the British stereotype in an effort to connect with audience perceptions and expectations. Her analysis also demonstrates that the stereotypical image held by people who have visited the country is not very different from the one held by those who have not, suggesting that greater familiarity does not necessarily overcome simplifications. As Justus, Kieti, \& Nthiga (2018) point out in their analysis of the stereotypical image of the Maasai people projected by Kenyan films, tourist satisfaction levels increase when their tourist experience is in keeping with the expectations created by projected stereotypes.

\subsubsection{Orientalist stereotypes}

Many stereotypes that simplify the non-Western Other contribute to the creation of images characterised by primitivism, irrationality, sensuality, and exoticism (Bandyopadhyay; Morais, 2005; Caton; Almeida-Santos, 2008). However, as Tzanelli (2003) demonstrates, this stereotypical image also affects Europe's peripheral regions, specifically southern Italy, Portugal, Spain and Greece. Drawing on the ideas of Said (1979) and on critical theory, the author studies the romantic, folkloric, "Orientalist" image of Cephalonia, and of Greece as a whole, projected in Captain Corelli's mandolin (John Madden, 2001).

In relation to Portugal, Cordeiro (2011) highlights the similarities between the images projected in films and tourist guides that characterise the country as a sensual, pre-modern paradise. Bencivenga, Chiarullo, \& Colangelo (2015) and Urso (2015) show that films set in the Italian regions of Basilicata and Puglia project an image founded on certain positive aspects of southern Italian stereotypes, such as slow-paced, simple and relaxed lifestyles, or a feeling of timelessness far removed from the modern world.

In the case of Spain, the simplified image of the country, founded on a kind of Orientalisation of Andalusia, has its roots in the literary and artistic production of the European Romantic travellers of the 19th century (Galí-Espelt, 2005; 
Navarrete, 2009; Poutet, 1995). Stereotypes of Spain have inspired numerous cultural productions, both domestic and international, even to the point of creating a genre of its own, known as Españolada, which can be found in literature, the performing arts, popular music, and films (Navarrete, 2009).

Both the Españolada genre and the long-standing stereotypes on which it is based have been called into question in many regions of Spain. Yet many foreign productions set in the country continue to evoke them, such as Vicky Cristina Barcelona (Woody Allen, 2007). This film presents tourist attractions that fit the image cultivated by Barcelona's tourism promoters. As Marine-Roig (2011a; 2011b), Richards (2007) and Smith (2005; 2007) all point out, it is an image based on Catalan identity, cosmopolitanism and Mediterraneanism. However, these attractions are framed in a story that is pure Españolada: the conflict between (foreign) reason and (native) passion, with characters reflecting the Don Juan and gypsy stereotypes along with countless motifs associated with Andalusian folklore. The film thus projects two antithetical images of Barcelona (Nieto-Ferrando et al., 2021).

\subsubsection{Stereotypical image vs. non-stereotypical image}

Beeton (2004) argues that dissociation between projected images is counterproductive for tourism promotion. This author compares what she calls "dominant projected images" of Australia, founded on stereotypically idyllic scenery, and the image projected by films about the outlaw Ned Kelly, with a more realistic representation of the Australian bush and its history. In this case, the stereotypical image comes from the institutions promoting the destination, not the films, which question that image.

However, as Nieto-Ferrando et al. (2021) point out, in the case of Vicky Cristina Barcelona and other international productions set in Barcelona, where the projected image differs from the official image, the two images can complement one another. The stereotypical projected image could be a factor that appeals to audiences with no direct experience of Barcelona. Viewing these films would satisfy the expectations associated with a preconception with considerable weight outside Spain. At a later stage, the experience of Barcelona itself (the organic source of the image) and conventional tourism-inducing sources (advertising) would help reshape this preconception into something closer to the desired image of the city. This could be confirmed by correlating the image projected by these films with the image projected by officially sponsored advertisements and content generated on social media by tourists who have already visited the city, as an indicator of perceived image.

\subsubsection{Specificity of audiovisual fiction}

Some studies have also analysed the capacity of audiovisual fiction to create-or increase-awareness of the existence of a place that has no recognisable attractions (Croy, 2010; Tooke; Baker, 1996). In such cases, its image is linked to an audiovisual production through associations between the locations where they are filmed or set and their storylines and characters (Hao; Ryan, 2013).

\subsubsection{Iconic attractions}

Riley, Baker, \& Van-Doren (1998) argue that one of the effects of films and series is to turn the places where they are filmed or set into what they call "icons". These icons are tourist attractions that acquire importance through their association with concepts, themes or feelings resulting from the interaction of the location with different elements of the narrative and the story, beyond the inherent features of the place itself.

This, however, is not the only meaning given to the term "icon" that can be found in the literature. In their categorisation of films with the capacity to create destination images, Mestre, Del-Rey, \& Stanishevski (2008) consider "icon films" to be those whose aesthetic values become infused in the places where they are set. Examples of this are Zhang Yimou's China or Pedro Almodóvar's Spain. These are distinguished from what the authors call "pastiche films", which cobble cultural stereotypes together, as in the case of the scenes set in Seville in Mission: Impossible II (John Woo, 2000), and "tourist poster films", where the story is placed at the service of displaying the tourist attractions of the location. Occasionally, the term "icon" is also used to refer to a destination's tourist attractions or to destination attractions enhanced by audiovisual fiction (Busby; Haines, 2013; Rodríguez-Campo; Fraiz-Brea; Rodríguez-Toubes-Muñiz, 2012).

The definition of "icon" given by Riley, Baker, \& Van-Doren (1998) is somewhat confusing, but it has the merit of pointing to the specific nature of audiovisual fiction's effect on destination image. The origins of some of the associations that the authors point out pre-date their use in a film or series, such as the association of the prairies of South Dakota with Native American cultures in Dances with wolves (Kevin Costner, 1990), but others are created exclusively by the audiovisual production. On the one hand, tourist attractions featured in some scenes can be transformed into what Bencivenga, Chiarullo, \& Colangelo (2015) call "tangible icons" that endure in the spectator's memory. An example of this, these authors suggest, is the scene where Anita Ekberg and Marcello Mastroianni bathe in the Trevi Fountain in La dolce vita (Federico Fellini, 1960). On the other hand, a location or setting may ac-

Many stereotypes that simplify the non-Western Other contribute to the creation of images characterised by primitivism, irrationality, sensuality, and exoticism. However, this stereotypical image also affects Europe's peripheral regions, specifically southern Italy, Portugal, Spain and Greece 
quire symbolic associations merely by its presence in a film or series. As Gundle (2002) notes, Rome's image acquired a glamorous dimension following La dolce vita, as prior to this, in the years immediately after World War II, Italian neorealism had projected an image of dire poverty. Similarly, Riley, Baker, \& Van-Doren (1998) highlight the romantic associations acquired by the covered bridges in Winterset, lowa, following their appearance in The bridges of Madison County (Clint Eastwood, 1995), and the associations with feminist liberation of Arches National Park in Utah thanks to Thelma \& Louise (Ridley Scott, 1991).

\subsubsection{Connotative attractions}

In semiotic terms, many of the associations identified by Riley, Baker, \& Van-Doren (1998) are connotations. Barthes (1985) describes connotation as the result of the process of transformation of a denotative sign into the signifier of a new sign. The signified of this signifier extends beyond "literalness". While in films and television series, denotation is driven by analogy, by the similarity between signifier and signified, connotation spills over the boundaries of analogy and into the symbolic. But the audiovisual image is always connotative. This is because the profilmic space -what the camera shows us- can be imbued with symbolic meanings. Moreover, mise-en-scène, framing, editing and intertextuality (particularly generic intertextuality) are also potential sources of connotation (Gubern, 1994).

The romantic connotation of the covered bridges in Winterset in The bridges of Madison County is a product of the text itself, while the associations of Arches National Park with the feminist struggle based on Thelma \& Louise arise from the text and from generic intertextuality, as one of the recurring themes in the road movie genre to which this film belongs is the quest for freedom. These connotations of romanticism or feminist liberation are not suggested in any of the features of the locations themselves, but in their connection to the story and its characters.

Some connotations have acquired a certain degree of consolidation due to their presence in numerous films. The romantic connotations that Switzerland has for Indian tourists thanks to certain Bollywood pictures (Josiam et al., 2014) constitute an example of this. The mere presence of an Alpine mountain in an Indian film triggers this association in the spectator, without the need to clarify the connection. Like stereotypes, consolidated connotations can facilitate narrative economy in a film, and they are reinforced by the need for their practical application to understand and interpret the story.

\subsection{Texts, reception and placement}

Recent studies make use of textual analysis with the aim of pinpointing the source of the tourism-inducing capacity of films or series, as well as the processes triggered by spectators in their interaction with audiovisual productions. Many of the findings could have an impact on the placement of destinations or attractions, although most of the studies that have explored film- and television-induced tourism from this perspective are purely speculative.

\subsubsection{Audiovisual texts}

The research suggests that the tourism-inducing capacity of audiovisual fiction lies in the combination of location exposure, a story that captures the spectator's interest and is associated with the location, and characters, preferably played by celebrities, with whom spectators can identify (Bolan; Williams, 2008; Macionis, 2004; Riley; Van-Doren, 1992; Riley, Baker, \& Van-Doren, 1998). These factors may be interconnected or one may stand out above the others. According to Hahm \& Wang (2011) and Hudson, Wang, \& Moreno-Gil (2011) the scenery shown has the biggest impact. Riley \& Van-Doren (1992) and Riley, Baker, \& Van-Doren (1998) also acknowledge the importance of the prolonged exposure of the scenery but argue that it is the story that vests it with thematic and affective associations that can turn it into a potential tourist attraction. Studies like those by Frost (2010) and Hao \& Ryan (2013) dismiss the dichotomy between setting and story, or at least describe it as something more complex. Along the same lines, Pan \& Tsang (2014) specify that in classical audiovisual storytelling everything is subordinated to the narrative in such a way that the presentation of the scenery has to be integrated into it. According to these authors, the higher level of integration between setting and story is why Crocodile Dundee (Peter Faiman, 1986) had a more significant effect on Australia's image and on increasing tourist numbers to the country than the film Australia (Baz Luhrmann, 2008).

Most of these studies make furtive approaches to audiovisual theory and analysis. The articles by Leotta (2009) and Reijnders (2009) take it a step further. The first infers reasons for the tourist interest in Karekare Beach in New Zealand triggered by The piano (Jane Campion, 1993). Leotta (2009) suggests that the importance of the setting in the story and the significance of its mise-en-scène are the main tourism-inducing factors. However, this scholar's reading of the film transforms the characters and their actions into an allegory for the tourist experience in post-colonial countries like New Zealand. The polysemous nature of audiovisual texts often inspires these types of symptomatic interpretations, which are difficult to corroborate. But the analysis of the image projected by an audiovisual production only requires the study of what is evident in the text, and more specifically, the treatment of the tourist destination or attraction in the mise-en-scène, the framing, and their relationship, as part of the setting of the story, with other narrative variables.

The analysis of tourist destinations and attractions in the context of audiovisual storytelling and representation needs to be complemented with a study of its effects on audiences, in relation to the perceived image, motivations, decisions or even visits 
In this context, Reijnders (2009) analyses the features and functions of the setting in the detective series Inspector Morse (Zenith Productions, Central Independent Television, Carlton UK Productions, WGBH, 1987-2000), Baantjer (Endemol Entertainment, 1995-2006) and the various Swedish miniseries produced between 1994 and 2006 featuring Inspector Kurt Wallander. This author highlights the importance of the setting in the generic features of each episode, which locate the action using the attractions of Oxford, Amsterdam, and southern Sweden, respectively, recognisable for their stereotypical quality. The settings where the characters are shown, the way those settings are characterised, and even the cinematography supports this simplified image, contributing to the reinforcement of the audience's familiarity with the locations. According to Reijnders, the role of the setting in the story's trigger moment, the structural sequence that breaks with the everyday and propels the protagonists into the adventure, is equally important. In all cases, a contradiction is established between the stereotypical, idyllic setting and the discovery of a dead body. This contradiction places the emphasis on both the crime and the setting where it takes place.

Reijnders considers the success of tours offered in Oxford, Amsterdam and southern Sweden based around these three series to analyse how they project an attractive image to tourists. Other notable studies along these lines include those by Luo et al. (2014) and Nieto-Ferrando (2020). The first draws on the textual analysis models proposed by Monaco (2000) and Rose (2001), among others, to study Romance on Lushan Mountain (Huang Zumo, 1980) and its sequel, Love is the last word (Romance on Lushan Mountain 2010) (Zhang Yu, 2010), two films that have had a significant impact on the image of this tourist attraction. The authors also argue that this effect is due to the way the locations are represented and form part of the story.

Nieto-Ferrando (2020) draws on a corpus of films that have had an impact on the locations where their stories are set, as corroborated in the study, to infer a series of constants in their treatment of the setting. Based on these constants, he develops a systematic method for analysing films and series with tourism-inducing potential. This method references contributions to audiovisual textual analysis by Aumont \& Marie (1990) and Casetti \& Di-Chio (1991), studies of audiovisual storytelling by Gaudreault \& Jost (1995), García-Jiménez (1993) and Chatman (2013), and screenplay analysis by Sánchez-Escalonilla (2014). Gómez-Morales \& Nieto-Ferrando (2021) have expanded on this work to include the analysis of film music, in view of its capacity for eliciting emotions.

The method takes into account the interactions between settings, characters and storyline, considering: 1) the duration of the tourist attractions' appearance in the films (without decontextualising them from the scenes and sequences in which they appear); 2) the interaction between characters and setting, whether verbal, visual or expressive, and the capacity of the setting to condition the characters' actions; and 3) the location of the setting in the structure of the story, as its impact will differ depending on whether it appears in sequences of minimal importance in structural terms, in the inciting incident, in the transitions between acts or in the climax.

Nieto-Ferrando (2020) and Gómez-Morales \& Nieto-Ferrando (2021) suggest that the analysis of tourist destinations and attractions in the context of audiovisual storytelling and representation needs to be complemented with a study of its effects on audiences, in relation to the perceived image, motivations, decisions or even visits. This has been corroborated by the study by Hahm \& Wang (2011) of the impact of Lost in translation on the attributes of Tokyo's image as a tourist destination. According to these authors, the fact that the Park Hyatt Hotel in Tokyo has an identity closely tied to the film's protagonist -and therefore has a significant impact on the actions of the other characters, as suggested in Nieto-Ferrando's (2020) model-constitutes a considerable enhancement of the perception of the city's "quality of accommodation" attribute.

\subsubsection{Reception}

Some studies seek to explain the effects of audiovisual fiction on a destination's perceived image, and on tourism in general, based on the processes triggered by the interaction between text and spectator. In their analysis of the impact of Before sunrise (Richard Linklater, 1995) on Vienna's attributes, based on the categorisation of attributes established by Baloglu \& McClearly (1999), Kim \& Richardson (2003) cite the concept of "vicarious experience" developed by Riley \& Van-Doren (1992), as well as the concept of "familiarity". According to these authors, the experience of the destination entails changes to its image. The presence of the destination in a film constitutes a kind of experience of that destination for the spectator, which therefore has an impact on its image. This prior experience would create familiarity with the destination and would reduce the perception of risk that potential consumers may have of an intangible product like tourism. Some researchers go further and argue that viewing is a kind of prior consumption of the destination (Corbin, 2014; Gibson, 2006; Bencivenga; Chiarullo; Colangelo, 2015), enhanced by the spectacular presentation of its attractions and the meaning they acquire through their relationship with the stories.

However, Kim \& Richardson (2003) are not able to confirm whether familiarity or vicarious experience is a determining factor in changes to image attributes. The authors posit that familiarity requires the recurring appearance of an attraction or destination in numerous productions. In any case, the concept of "vicarious experience" is useful for shedding light on processes triggered by the spectator while watching a film or television series: suspension of disbelief, various 
types of immersion, identification (with the camera and with characters) and involvement with the story and the diegesis. It is essential to consider these processes in order to analyse the tourism-inducing effects of audiovisual productions (Yang; Vanden-Bergh; Lee, 2017).

Kim \& Kim (2018) argue that any analysis of film- and television-induced tourism needs to consider the participation of the audience in the texts. This participation is multidimensional. On the one hand, there is a correlation between what they call "production values" (story, topic, characters, mise-en-scène and framing, in both aesthetic and narrative terms) and audience participation, as Kim \& Assaker (2014) also point out. On the other, the researcher should take into account the different types of audience participation, including: 1) "parasocial interaction", or a feeling of closeness to the character; 2) emotional ties that can be established with the stories, which can attribute symbolic meanings to particular settings, among other things; 3 ) the degree to which spectators relate the story to their own personal experiences, establishing parallels with it or integrating it into the repertoire of resources that enable them to make sense of their own environment; and 4) the degree to which the audiovisual production can influence spectator behaviour. These dimensions of audience participation all interact with each other.

In their analysis of the reception of Korean television series in Taiwan, Su et al. (2011) correlate the spectator's affective attitude towards the characters (positive, negative or neutral), the spectator's parasocial attachment to the character (feelings of closeness or distance), the character's attitude towards the location, the spectator's attitude towards the location, and cultural proximity. The authors conclude that there is a significant relationship between the degree of parasocial attachment to the characters and the effect of the series on the audience. Where there is a high level of parasocial attachment, a character's positive attitude towards a tourist destination or attraction used as a setting can foster a similar attitude in the audience. This effect is enhanced when there is a degree of cultural proximity between the series and its audience, as in the case they analyse.

Studies by Kim \& Assaker (2014), Kim \& Kim (2018) and Su et al. (2011) expand the horizons of tourism research to include reception studies. These can also be complemented by studies focusing on textual analysis by Nieto-Ferrando (2020), Gómez-Morales \& Nieto-Ferrando (2021), Luo et al. (2014), and Reijnders (2009).

\subsubsection{Destination placement}

Studies that connect textual analysis and reception studies are useful for analysing projected image and perceived image from the perspective of destination placement. Product or brand placement involves the insertion of products or brands in an audiovisual production for advertising purposes. Studying audiovisual fiction-induced tourism from this perspective means moving beyond Gartner's (1993) view of films and television series as autonomous (i.e. "non-inducing") agents in tourist destination image formation (Hudson \& Ritchie, 2006a; Shani et al., 2009).

Nieto-Ferrando (2020) suggests that audiovisual fiction offers certain advantages for the placement of tourist destinations and attractions. These form part of the setting, the place where the events of the stories unfold, with a significant impact on shaping those events. The setting therefore constitutes a key element in audiovisual storytelling. This is why a film or television production is more suitable for promoting the setting (its own setting) than any other product. Destination placement in an audiovisual production can even turn into a newsworthy event, which would not normally happen with other types of placement (Redondo, 2012).

Many of the studies reviewed consider that advertising a tourist destination by placing it in an audiovisual production is more effective than conventional advertising (Hudson; Ritchie, 2006a; Hudson; Wang; Moreno-Gil, 2011; Shani et al., 2009; Rodríguez-Campo; Fraiz-Brea; Rodríguez-Toubes-Muñiz, 2011; Kim; Richardson, 2003). Two important issues that are debated in these studies are the extent to which tourism promoters use this advertising strategy and the difficulty associated with reconciling their interests with those of the producers.

With respect to the first issue, Frost (2010) points out that governments are working hard to bring film and television productions to their regions. Tourism producers are taking a greater interest in understanding how audiovisual productions work so that they can develop strategies to influence the image they project. Bolan \& Williams (2008) suggest that so far tourism promoters have only tended to act to enhance the effect of audiovisual productions after they are released, when, according to Horrigan (2009), they should be getting involved in projects right from the conception stage. However, Basilicata coast to coast (Rocco Papaleo, 2010) in Italy (Bencivenga; Chiarullo; Colangelo, 2015) and Vicky Cristina Barcelona in Spain (Zamorano, 2020) provide evidence of joint action between governments and production studios from the very first stages of the projects. Both productions received government support, and this affected the content in both cases, including the requirement that the names of the locations had to be included in the film titles.

The second issue relates to the very different objectives of audiovisual producers and tourism promoters ( $\mathbf{O}^{\prime} \mathrm{Connor}$; Flanagan; Gilbert, 2008). Efforts to appeal to film or TV audiences may not be in keeping with the objectives of tourism promotion policies, even when those policies involve destination placement. As noted above, there are no divergences between the image projected in Basilicata coast to coast and the image desired by the region's tourism promoters (Bencivenga; Chiarullo; Colangelo, 2015). However, despite the government support it received, the image projected by Vicky Cristina Barcelona differs, at least partly, from the image promoted by the region's authorities (Nieto-Ferrando et al., 2021). 
As it involves the setting as a narrative variable, the nature of tourist destination or attraction placement itself creates these kinds of problems. The insertion of product or brand advertising in a film or television production is clearly defined and delimited: it appears only in certain scenes and under specific circumstances. This may also be the case of a tourist attraction, but more commonly much of the story's setting can effectively be advertising the location. This suggests that any adjustments to the advertising of the tourist attraction to meet the needs of tourism promoters runs the risk of resulting in a "tourist poster film", as Mestre, Del-Rey, \& Stanishevski (2008) define it, to the detriment of the production.

\subsection{Which destinations and which audiovisual productions?}

\subsubsection{Destinations known or unknown}

Di-Cesare, D’Angelo, \& Rech (2009) and O'Connor, Flanagan, \& Gilbert (2008) argue that audiovisual fiction is more likely to change the image of destinations that are exotic, unfamiliar or remote. If the destination is already well-known, the production merely reinforces pre-existing images and it is difficult to distinguish its impact from that of so many other stimuli, especially on overall image (Bencivenga; Chiarullo; Colangelo, 2015).

Hudson, Wang, \& Moreno-Gil (2011) found that the cultural proximity of the location is also an important factor. Working with spectators in the United States, Canada and Spain, they determined that the effect of The motorcycle diaries on the attributes of Latin America's image was different among Spanish viewers, which they attributed to Spain's stronger cultural ties to the region.

\subsubsection{Television, film and genres}

There is less agreement on the question of which types of productions have greater tourism-inducing capacity. The debate on this question involves two areas: the differences between television and film fiction, and the genres that can be more effective.

Kim \& Long (2012) and O'Connor, Flanagan, \& Gilbert (2008) suggest that television series have a greater impact than films. The serial nature and longer reception time of television series result in a higher level of spectator identification, empathy, emotional connection and parasocial interaction with the characters, as well as a greater degree of engagement with the stories and the locations where they take place. Added to this is the cumulative effect of repeated exposure to those locations (Beeton, 2016). Su et al. (2011) draw on the "cultivation paradigm" to argue that the cumulative effect of ongoing exposure to a destination's projected image brings the audience's perceived image closer to it. Kim \& Long (2012) acknowledge that television is at something of a disadvantage compared to film when it comes to the emphatic display of scenery, particularly in genres like the soap opera. However, current television production conditions have raised the formal features of TV series to a cinematic level.

Numerous researchers have also pointed to the need to analyse which genres may have a bigger tourism-inducing effect, particularly on destination image (Beeton, 2016; Hahm; Wang, 2011; Hudson; Ritchie, 2006a; Hudson; Wang; Moreno-Gil, 2011; Kim; Richardson, 2003; Riley; Baker; Van-Doren, 1998; Roesch, 2009; Shani et al., 2009). Different genres have different target audiences (Kim; Long; Robinson, 2009; Redondo, 2012) and are identifiable by their storylines. Redondo (2012) suggests that distinguishing genres can help tourism promoters to manage destination placement in a more informed way. With this in mind, this researcher correlates the genre preferences of viewers with their visits to different types of destinations. His findings include the identification of a significant positive correlation between a preference for adventure and suspense films and beach destinations, and between the comedy, suspense and drama genres and urban destinations, as well as a negative correlation between musicals and beach destinations, and between family and adventure films and urban destinations.

The analysis of genres can also help identify which genre is most appropriate for destination image creation. Historical fiction, for example, is generally set in heritage attractions, while certain types of Westerns (Beeton, 2015) and road movies are more likely to display natural scenery. Frost (2006) argues that historical films can have an especially powerful influence on tourism, as the use of heritage sites as locations is one of the specific features that give them their identity as a genre. In their analysis of the projected image of Basilicata in Basilicata coast to coast and its impact on Italian tourism, Bencivenga, Chiarullo, \& Colangelo (2015) demonstrate the tourism-inducing capacity of the road movie genre to which the film belongs. Road movies are structured around a trip that gives special importance to the settings where the events unfold, and they depict a profound change in the characters that is directly linked to the travel experience.

\section{Conclusions}

The objective of this article has been to identify gaps and conceptual limitations in research on the influence of audiovisual fiction on the image of tourist destinations and attractions, and to consider how audiovisual text theory and analysis could contribute to addressing them. This in turn can contribute to bridging the gaps between tourism studies and audiovisual studies, which, as Beeton (2016) and Connell (2012) point out, is essential for furthering the research on the tourism-inducing capacity of audiovisual fiction. 
To this end, this article has presented a review of the literature (articles published in English and indexed in Web of Science and Scopus) dealing with the relationship between audiovisual fiction and tourism destination image. Section 3 above categorises the research according to the objectives and topics of the articles, the relationship between destination image and tourist motivations or intentions to visit, and the use of audiovisual theory and analysis, while Section 4 offers a critical and conceptual analysis of the main contributions of the research.
Audiovisual fiction is more likely to change the image of destinations that are exotic, unfamiliar or remote. If the destination is already well-known, the production merely reinforces pre-existing images and it is difficult to distinguish its impact from that of so many other stimuli, especially on overall image

This review has identified the following research gaps:

C1) Unequal attention is given to the different aspects of the impact of audiovisual fiction on destination image. There is also no analysis of the suitability of the attribute categories used to measure the tourism-inducing effects of films or series.

Most of the research explores positive effects of audiovisual fiction on overall perceived image or on some of its attributes. Less attention is given to negative effects on perceived image, and films that produce no significant effects despite the use of destination placement are practically ignored. As Redondo (2012) points out, the absence of failure analysis limits our understanding of the outcomes of advertising strategies aimed at enhancing destination image through audiovisual fiction. There is also debate about the negative effect of "negative storylines" (although the meaning of this term lacks a clear definition) and their relationship with the reality of the location where a production is set and with other media texts that explore that reality along with audiovisual productions.

In the case of destination attributes, the categories used are taken from previous studies, which in turn are based on content analysis of advertising texts (tourist brochures and guides). However, promoting tourist destinations is never the main objective of a film or television series. This means that a useful method for measuring the effects of advertising material on destination image is not necessarily suitable for analysing fiction.

C2) Studies of stereotypical projected or perceived image rarely relate them to other aspects of the image.

Studies also explore the projection of stereotypes associated with destinations and their influence on tourist expectations. Some of these have approached this question from the perspective of cultural studies or even critical theory, particularly when the stereotypes reinforce Orientalist images. There are no studies relating perceived stereotypes to overall negative projected and perceived image or to negative changes to attributes. There is also no research analysing contradictions between the projection of stereotypical images in productions in which a destination is placed and the image of the same location projected by tourism promoters. There is an evident lack of understanding of how stereotypes work in audiovisual storytelling.

C3) There are studies that identify the specific contribution of audiovisual fiction to destination image in terms of two of the definitions given to the problematic notion of "icon" in Riley, Baker, \& Van-Doren (1998): the icon as a connotation of an attraction based on its relationship to other elements of the story; and the "tangible icon" based on individual contradictory or ironic scenes.

C4) The research suffers from a lack of attention to audiovisual theory and analysis, despite the fact it inevitably calls for an interdisciplinary approach. The debates over the importance of scenery, characters or storyline suggest a non-holistic conception of TV series and films, where each element that comprises them has its own meaning and a meaning based on its relationship to the other elements.

C5) Descriptive studies predominate over explanatory studies. Explanatory studies are more likely to draw on audiovisual textual analysis.

Most of the studies on the effects of audiovisual fiction on perceived destination image are descriptive. There are also clear difficulties associated with collecting information about these effects. Many studies make use of convenience samples of spectators to measure the impact of audiovisual fiction on destination attributes. However, there is clearly a growing interest in the processes triggered by the spectator while watching films or series, but more for the analysis (explanatory, in this case) of motivations and intentions to visit than of the images.

C6) Some authors suggest that audiovisual fiction is especially suitable for the placement of tourist destinations or attractions, as they form part of the setting of the story. However, the impact of films and television on destination image has rarely been analysed from this perspective. Debates focus on whether tourism promoters make use of this strategy or the differences between the interests of promoters and the aims of film and television producers.

C7) Much of the research takes the view that the effect of audiovisual fiction on destination image is more significant when the destination is not as well-known. In these cases, its image may be associated exclusively with its presence in an audiovisual production. However, the level of prior knowledge about a destination depends on the audience. 
c8) There is a recurring debate in the literature about the types of productions capable of influencing destination image, motivations and intentions to visit. Studies of film fiction predominate over television series. Numerous studies stress the need to consider the particular characteristics of genres, as they may influence destination image in different ways. However, there are very few studies that actually explore this question.

c9) In general terms, there is a predominance of case studies in the literature. Connell (2012) claims that this is common in the early years of a field of research, but that it hinders the formulation of generalisations. When a study draws on a corpus of audiovisual productions, the selection criteria for the sample are often unclear.

\subsection{Recommendations for future research}

Based on the results and conclusions of this review, a number of recommendations can be offered for further research on film- and television-induced tourism, and particularly the impact of audiovisual fiction on destination image. These recommendations constitute the main contribution of this study.

The recommendations are:

1) Samples of audiovisual productions should be selected according to rigorous criteria (C1, C9)

Attention is needed to both successes and failures in the use of audiovisual fiction to influence destination image, and research needs to move beyond case studies. This could be achieved through an appropriate, reasonably large selection of audiovisual productions. The basic criteria should be the geographical location where they are set or filmed, the target audience (without viewers, there is no effect) and a high level of exposure of the tourist attractions. With this foundation, the criteria can be further specified based on the objective of the study. In this way, researchers would avoid selecting films or series that serve the sole function of exemplifying a particular hypothesis (such as positive changes to perceived image) that is then asserted as a theory, as is the case in many of the studies analysed.

2) Destination image attributes should be reviewed with attention to the specific characteristics of audiovisual fiction (C1) Along with the usual attribute categories, the analysis of the effect of audiovisual fiction on destination image attributes should include others inferred from content analysis of audiovisual fiction texts with tourism-inducing potential.

3) In addition to the audiovisual production itself, the paratexts associated with it and other texts related to the destinations should also be analysed (C1, C5, C7)

It is essential to identify the specific contributions of films and TV series in relation to other sources of image creation, particularly media sources. A high level of media exposure increases familiarity with a destination and may dilute the effect of the audiovisual production on its image. If it creates a negative perception of the destination, a higher level of media exposure may also neutralise a positive representation of it in an audiovisual production.

In many cases, the impact of an audiovisual production on a destination's image, and on tourism in general, is also reliant on other media to boost its effect. The paratexts associated with audiovisual productions may create expectations about the relationship between the film or series and a destination, or they may simply help to identify its locations when the setting of the story is not referential. The reception of audiovisual productions is conditioned by these paratexts.

\section{4) Audiovisual texts should be analysed systematically (C1-C4, C6, C8)}

Only by considering how tourist destinations function in audiovisual storytelling and representation can the complexity of the projected image in films and TV series and its effect on perceived image be fully understood. Relating these studies to the analysis of reception and of the effect on audiences will result in research that is more explanatory (why and how) than descriptive (what).

Audiovisual text analysis, together with the study of reception, effects and audiences, can help to explore the following issues: a) The failure of success of an audiovisual production to influence perceived image, given that both may be related to the degree and type of interaction between the tourist attractions displayed and the storylines or characters.

b) The apparent contradiction between a negative projection of a destination in a film or series and a positive effect on perception or on visits to that destination. A negative conclusion to a character's story does not necessarily mean a negative representation of the setting where it takes place.

c) The projection of stereotypes and its effect on expectations associated with destinations, given the frequent use of stereotypes in classical audiovisual storytelling.

d) The transformation of certain tourist attractions into "icons".

e) The identification of contradictions in the image projected by audiovisual productions. The placement of tourist attractions consistent with the image desired by tourism promoters may clash with the use of representative and narrative strategies associated with stereotypes. 
f) The identification of the types of audiovisual productions with the biggest tourism-inducing capacity.

5) Reception, effects and audience should be conceptualised in more complex terms (C1-10)

Potentially useful approaches include the conceptual grounding offered by the cultivation paradigm, by research on the media as agents of socialisation and their role in the social construction of the individual's reality, as posited by Beeton (2006), or by the uses and gratifications paradigm, where audiovisual fiction viewing may be motivated by the search for information about a potential holiday destination.
This research has identified the specific contribution of audiovisual fiction to destination image in terms of two of the definitions given to the problematic notion of "icon": the icon as a connotation of an attraction based on its relationship to other elements of the story; and the "tangible icon" based on individual contradictory or ironic scenes

It is essential to take audience diversity into account. Audiovisual fiction can attribute connotative meanings to certain destinations, but such connotations ultimately depend on the cultural background of the spectator. The same is true of stereotypes and the degree of familiarity with a destination. Contributions from cultural studies, especially those focusing on the interaction between media texts and their receivers, can help explain the diversity of audiences and of their reception of and negotiation with texts, as demonstrated by Mercille (2005).

In methodological terms, there does not seem to be any justification for the continued use of experimental designs that analyse the effect of audiovisual productions on a convenience sample of the audience. Recent studies have highlighted the diversity of methods available for research on film- and television-induced tourism (Sánchez-Castillo, 2020; 2021). These include the vast amount of information created by tourists and fans of films and series on social media describing their tourist and viewing experiences. Content analysis of this information could be decisive for the development of a more accurate picture of the impact of audiovisual fiction on destination image.

\section{6) The tourism-inducing potential of film and television fiction needs to be determined and differentiated (C8)}

While films and television series share many characteristics, the specific features of each medium should also be taken into account. This means abandoning the treatment of television fiction as an extension of film fiction, and addressing the noticeable imbalance in the research, which is dominated by studies of films. The substantial audience that television series now enjoy (especially with content streaming platforms), the enhancement of their formal features (enabling them to display tourist attractions in a manner comparable to films) and the particular relationship, extended over time, that spectators establish with them due to their serial nature, are all indisputable arguments for giving this medium more attention.

\section{7) Intertextuality should be given more attention, particularly generic intertextuality (C2-C4, C8)}

It is essential to identify the specific characteristics of the different genres to determine their capacity to influence destination image and motivations and intentions to visit. But genre theory, underpinned by intertextuality, could help explain how stereotypes function in texts and their effect or the consolidation of connotative meanings associated with certain destinations.

Films or series belonging to a given genre are characterised by their similar content and a similar formal organisation (Altman, 2000). This gives them a somewhat repetitive and predictable quality, with similar characters and conflicts that are resolved in much the same way, although the details vary. In this sense, a genre offers familiar characters, themes and settings. Similarly, stereotypes, the redundant use of connotative attractions, and the generic coding of characters, settings or themes can facilitate narrative economy and the development of the story, although their practical application by the spectator is required. This enhances their effectiveness.

\subsection{Limitations}

The main limitation of this study is its isolation of the construction of destination images from the set of factors that guide the tourist's decision-making process. These processes interact with each other. Future studies should focus on the critical analysis of research on the effect of audiovisual fiction on tourist motivations and intentions to visit. A review is also needed that considers the conceptualisation of reception, effects and audiences in studies of film- and television-induced tourism, and the method used for their analysis.

Furthermore, this review has analysed research on the influence of audiovisual fiction on destination image prior to visiting the destination, as this has been the focus of most scholarly attention. However, destination image fluctuates depending on the tourist's relationship with the destination. That image may change to different degrees during the tourist experience itself (the organic image generated in situ) or sometime after visiting the
The paratexts associated with audiovisual productions may create expectations about the relationship between the film or series and a destination, or they may simply help to identify its locations when the setting of the story is not referential 
location (Govers; Go; Kumar, 2007). Other questions to consider include the contrast between the expectations created by audiovisual fiction and the actual experience in the filmed locations (Chan, 2007), and the capacity of audiovisual productions to give meaning to a tourist attraction while visiting it and to consolidate its image after travelling there. Busby \& Haines (2013), Chan (2007) and Suhud \& Willson (2018) suggest that positive experiences at destinations enhance the tourist's attitude towards audiovisual productions set in those locations. It is possible that this new interest may tweak or reshape the organic image constructed through the tourist experience. It is also possible that tourism may induce the consumption of more audiovisual fiction set or filmed at the locations visited. In any case, these are areas of analysis that have yet to be explored extensively by researchers.

\section{References}

Almeida-Santos, Carla; Buzinde, Christine (2007). "Politics of identity and space: representational dynamics". Journal of travel research, v. 45, n. 3, pp. 322-332.

https://doi.org/10.1177/0047287506295949

Altman, Rick (2000). Los géneros cinematográficos. Barcelona: Paidós. ISBN: 9788449309793

Andsager, Julie L.; Drzewiecka, Jolanta A. (2002). "Desirability of differences in destinations". Annals of tourism research, v. 29, n. 2, pp. 401-421.

https://doi.org/10.1016/S0160-7383(01)00064-0

Aumont, Jaques; Marie, Michel (2015). L'analyse des films. Paris: Armand Colin. ISBN: 9782200602413

Baloglu, Seyhmus; McCleary, Ken W. (1999). "A model of destination image formation". Annals of tourism research, v. 26, n. 4, pp. 868-897.

https://doi.org/10.1016/S0160-7383(99)00030-4

Bandyopadhyay, Ranjan; Morais, Duarte (2005). "Representative dissonance: India's self and Western image". Annals of tourism research, v. 32, n. 4, pp. 1006-1021.

https://doi.org/10.1016/j.annals.2005.02.002

Barthes, Roland (1985). L'aventure semiologique. Paris: Editions du Seuil. ISBN: 9782020125703

Beerli, Asunción; Martín, Josefa D. (2004). "Factores que influyen en la imagen de los destinos". Annals of tourism research en español, v. 6, n. 2, pp. 357-384.

Beeton, Sue (2004). "Rural tourism in Australia - Has the gaze altered? Tracking rural images through film and tourism promotion". International journal of tourism research, v. 6, n. 3, pp. 125-135.

https://doi.org/10.1002/jtr.479

Beeton, Sue (2006). "Understanding film-induced tourism". Tourism analysis, v. 11, pp. 181-188. https://doi.org/10.3727/108354206778689808

Beeton, Sue (2015). Travel, tourism and the moving image. Bristol: Chanel View Publications. ISBN: 9781845415273 https://doi.org/10.21832/9781845415297

Beeton, Sue (2016). Film-induced tourism. Bristol, Blue Ridge Summit: Channel View Publications. ISBN: 9781845411206 https://doi.org/10.21832/9781845415853

Bencivenga, Angelo; Chiarullo, Livio; Colangelo, Delio (2015). "Film tourism in Basilicata". Almatourism. Journal of tourism culture and territorial development, v. 6, n. 4, pp. 241-260.

https://doi.org/10.6092/issn.2036-5195/4964

Bolan, Peter; Williams, Lindsay (2008). "The role of image in service promotion: focusing on the influence of film on consumer choice within tourism". International journal of consumer studies, v. 32, n. 4, pp. 382-390.

https://doi.org/10.1111/j.1470-6431.2008.00672.x

Bordwell, David (1990). Narration in the fiction film. London: Routledge. ISBN: 9780299101749 https://doi.org/10.4324/9781315002163

Bremond, Claude (1982). "La lógica de los posibles narrativos". En: Barthes, Roland; Julien Greimas, Algirdas J.; Bremond, Claude; Gritti, Jules; Morin, Violette; Metz, Christian; Todorov, Tzvetan; Genette, Gérard. Análisis estructural del relato. Buenos Aires: Tiempo Contemporáneo, pp. 87-110. ISBN: 9788485989027 
Busby, Graham; Haines, Callum (2013). "Doc Martin and film tourism: the creation of destination image". Tourism. An international interdisciplinary journal, v. 61, n. 2, pp. 105-120.

https://hrcak.srce.hr/106862

Busby, Graham; Klug, Julia (2001). "Movie-induced tourism: the challenge of measurement and other issues". Journal of vacation marketing, v. 7, n. 4, pp. 316-332.

https://doi.org/10.1177/135676670100700403

Cardoso, Lucília; Estevão, Cristina; Fernandes, Cristina; Alves, Helena (2017). "Film-induced tourism: a systematic literature review". Tourism \& management studies, v. 13, n. 3, pp. 23-30.

https://doi.org/10.18089/tms.2017.13303

Carroll, Nöel (2001). “On the narrative connection”. En: Carroll, Nöel. Beyond aesthetics: philosophical essays. Cambridge: Cambridge University Press, pp. 118-133. ISBN: 0521786568

https://doi.org/10.1017/CB09780511605970.009

Casetti, Francesco; Di-Chio, Federico (1991). Cómo analizar un film. Barcelona: Paidós. ISBN: 8475096689

Caton, Kellee; Almeida-Santos, Carla (2008). "Closing the hermeneutic circle? Photographic encounters with the other". Annals of tourism research, v. 35, n. 1, pp. 7-26.

https://doi.org/10.1016/j.annals.2007.03.014

Chan, Brenda (2007). “Film-induced tourism in Asia: a case study of Korean television drama and female viewers' motivation to visit Korea". Tourism culture \& communication, v. 7, n. 3, pp. 207-224.

https://doi.org/10.3727/109830407782212510

Chatman, Seymour-Benjamin (1990). Historia y discurso. La estructura narrativa en la novela y en el cine. Madrid: Taurus. ISBN: 9788430601301

Connell, Joanne (2012). "Film tourism - Evolution, progress and prospects". Tourism management, v. 33, n. 5, pp. 1007-1029. https://doi.org/10.1016/j.tourman.2012.02.008

Corbin, Amy (2014). "Travelling through cinema space: the film spectator as tourist". Continuum, v. 28, n. 3, pp. $314-329$. https://doi.org/10.1080/10304312.2014.900880

Cordeiro, Maria-João (2011). "Perpetuating tourism imaginaries: guidebooks and films on Lisbon". Journal of tourism and cultural change, v. 9, n. 3, pp. 249-258.

https://doi.org/10.1080/14766825.2011.620123

Correira-Loureiro, Sandra-Maria; Barbosa-De-Araujo, Arthur (2015). “Negative film plot and tourists' image and intentions: the case of City of God". Journal of travel \& tourism marketing, v. 32, n. 4, pp. 352-365.

https://doi.org/10.1080/10548408.2014.896769

Croy, W.-Glen (2010). "Planning for film tourism: active destination image management". Tourism and hospitality planning \& development, v. 7, n. 1, pp. 21-30.

https://doi.org/10.1080/14790530903522598

D’Alessandro, Libera; Sommella, Rosario; Vigagnoni, Lida (2015). “Film-induced tourism, city-branding and place-based image: the cityscape of Naples between authenticity and conflicts". Almatourism. Journal of tourism, culture and territorial development, v. 6, n. 4, pp. 180-194. https://doi.org/10.6092/issn.2036-5195/4960

Di-Cesare, Francesco; D’Angelo, Luca; Rech, Gloria (2009). "Films and tourism: understanding the nature and intensity of their cause-effect relationship". Tourism review international, v. 13, n. 2, pp. 103-111. https://doi.org/10.3727/154427209789604606

Dung, Yun-An; Reijnders, Stijn (2013). "Paris off screen: analyzing the Chinese tourist experience of cinematic Paris". Tourist studies, v. 13, n. 2, pp. 287-303.

https://doi.org/10.1177/1468797613498164

Echtner, Charlotte M.; Ritchie, J. R. Brent (1991). "The meaning and measurement of destination image". Journal of tourism studies, v. 2, n. 2, pp. 2-12.

https://doi.org/10.1177/004728759303100402

Ertz, Myriam; Sarigöllü, Emine; Karakas, Fahri; Chehab, Omar (2020). “Impact of TV dramas on consumers' travel, shopping and purchase intentions". Journal of consumer behavior, v. 20, n. 3, pp. 655-669.

https://doi.org/10.1002/cb.1891

Fakeye, Paul C.; Crompton, John L. (1991). "Image differences between prospective, first-time and repeat visitors to the lower Rio Grande Valley". Journal of travel research, v. 30, n. 2, pp. 10-16.

https://doi.org/10.1177/004728759103000202 
Fernández-Young, Anita; Young, Robert (2008). "Measuring the effects of film and television on tourism to screen locations: a theoretical and empirical perspective". Journal of travel \& tourism marketing, v. 24, n. 2-3, pp. $195-212$. https://doi.org/10.1080/10548400802092742

Frost, Warwick (2006). "Braveheart-ed Ned Kelly: historic films, heritage tourism and destination image". Tourism management, v. 27, n. 2, pp. 247-254. https://doi.org/10.1016/j.tourman.2004.09.006

Frost, Warwick (2010). "Life changing experiences: film and tourists in the Australian outback". Annals of tourism research, v. 37, n. 3, pp. 707-726.

https://doi.org/10.1016/j.annals.2010.01.001

Galí-Espelt, Núria (2005). La imatge turística del patrimoni monumental de Girona. Girona: Universitat de Girona. ISBN: 9788484582168

Gallarza, Martina G.; Gil-Saura, Irene; Calderón, Haydée (2002). "Destination image: towards a conceptual framework”. Annals of tourism research, v. 29, n. 1, pp. 56-78. https://doi.org/10.1016/S0160-7383(01)00031-7

Gartner, William C. (1993). "Image formation process". Journal of travel \& tourism marketing, v. 2, n. 2-3, pp. $191-216$. https://doi.org/10.1300/J073v02n02_12

Gaudreault, André; Jost, François (1995). El relato cinematográfico. Cine y narratología. Barcelona: Paidós. ISBN: 8449300924

Gkritzali, Alkmini; Lampel, Joseph; Wiertz, Caroline (2016). "Blame it on Hollywood: The influence of films on Paris as product location". Journal of business research, v. 69, n. 7, pp. 2363-2370.

https://doi.org/10.1016/j.jbusres.2015.10.005

Gibson, Sarah (2006). "A seat with a view: tourism, (im)mobility and the cinematic-travel glance". Tourist studies, v. 6, n. 2, pp. 157-178.

https://doi.org/10.1177/1468797606071475

Gómez-Morales, Beatriz; Nieto-Ferrando, Jorge (2021). "Emplazamiento e imagen de los destinos y los atractivos turísticos". En: Nieto-Ferrando, Jorge; Del-Rey, Antonia; Martín-Fuentes, Eva (eds.). Turismo inducido por el audiovisual. Revisión metodológica y propuestas de investigación transdisciplinar. Salamanca: Comunicación Social, pp. 49-74. ISBN: 9788417600464

Govers, Robert; Go, Frank M.; Kumar, Kuldeep (2007). "Virtual destination image: a new measurement approach". Annals of tourism research, v. 34, n. 4, pp. 977-997.

https://doi.org/10.1016/j.annals.2007.06.001

Gubern, Román (1994). La mirada opulenta. Exploración de la iconosfera contemporánea. Barcelona: Gustavo Gili. ISBN: 9788425213380

Gundle, Stephen (2002). "Hollywood glamour and mass consumption in postwar Italy". Journal of Cold war studies, v. 4, n. 3, pp. 95-118.

https://www.muse.jhu.edu/article/9276

Hahm, Jeeyeon; Upchurch, Randall; Wang, Youcheng (2008). "Millennial students, movies, and tourism". Tourism analysis, v. 13, n. 2, pp. 189-205. https://doi.org/10.3727/108354208785664229

Hahm, Jeeyeon; Wang, Youcheng (2011). "Film-induced tourism as a vehicle for destination marketing: is it worth the efforts?". Journal of travel \& tourism marketing, v. 28, n. 2, pp. 165-179.

https://doi.org/10.1080/10548408.2011.546209

Hall, Stuart (1997). "The spectacle of 'the other'”. In: Hall, Stuart. Representation: cultural representations and signifying practices, pp. 223-290. Thousand Oaks: Sage. ISBN: 9780761954323 https://doi.org/10.1080/10548408.2011.546209

Hao, Xiaofei; Ryan, Chris (2013). "Interpretation, film language and tourist destinations: a case study of Hibiscus Town, China". Annals of tourism research, v. 42, pp. 334-358.

https://doi.org/10.1016/j.annals.2013.02.016

Horrigan, David (2009). "Branded content: a new model for driving tourism via film and branding strategies". Tourismos, v. 4, n. 3, pp. 51-65.

http://www.chios.aegean.gr/tourism/vol4no3.pdf

Huang, Guanxiong (2013). "Mediating tourist landscape: a case study of media-induced tourism in China”. International journal of communication, v. 7, pp. 2678-2696.

https://ijoc.org/index.php/ijoc/article/view/1905 
Hudson, Simon; Ritchie, J. R. Brent (2006a). "Promoting destinations via film tourism: an empirical identification of supporting marketing initiatives". Journal of travel research, v. 44, n. 4, pp. 387-396.

https://www.doi.org/10.1177/0047287506286720

Hudson, Simon; Ritchie, J. R. Brent (2006b). "Film tourism and destination marketing: the case of Captain Corelli's Mandolin". Journal of vacation marketing, v. 12, n. 3, pp. 256-268.

https://doi.org/10.1177/1356766706064619

Hudson, Simon; Wang, Youcheng; Moreno-Gil, Sergio (2011). "The influence of a film on destination image and the desire to travel: a cross-cultural comparison". International journal of tourism research, v. 13, n. 2, pp. 177-190.

https://www.doi.org/10.1002/jtr.808

Itoo, Murtaza-Hassan; Nagar, Komal (2017). "Impact of negative portrayal of a destination in Bollywood movies on viewers' attitude towards the destination, intention to visit and destination image". Pacific business review international, v. 10 , n. 5, pp. 71-82.

http://www.pbr.co.in/2017/novSeven.aspx

Iwashita, Chieko (2006). "Media representation of the UK as a destination for Japanese tourists: popular culture and tourism". Tourist studies, v. 6, n. 1, pp. 59-77.

https://doi.org/10.1177/1468797606071477

Iwashita, Chieko (2008). "Roles of films and television dramas in international tourism: the case of Japanese tourists to the UK". Journal of travel \& tourism marketing, v. 24, n. 2-3, pp. 139-151.

https://doi.org/10.1080/10548400802092635

Josiam, Bharath M.; Spears, Daniel L.; Dutta, Kirti; Pookulangara, Sanjukta; Kinley, Tammy R. (2014). “'Namastey London': Bollywood movies and their impact on how Indians perceive European destinations". FIU hospitality review, v. 31, n. 4, pp. 1-22.

https://digital.library.unt.edu/ark:/67531/metadc1707419

Justus, Muchiri-Murithi; Kieti, Damiannah M.; Nthiga, Rita W. (2018). “Effect of stereotypes created by movies on the satisfaction of tourists with Movie Induced Tourism (MIT)". African journal of hospitality, tourism and leisure, v. 7, n. 4. https://www.ajhtl.com/uploads/7/1/6/3/7163688/article_17_vol_7_4_2018.pdf

Kim, Hyounggon; Richardson, Sarah L. (2003). "Motion picture impacts on destination images". Annals of tourism research, v. 30, n. 1, pp. 216-237.

https://doi.org/10.1016/S0160-7383(02)00062-2

Kim, Sangkyun (2012). "Audience involvement and film tourism experiences: emotional places, emotional experiences". Tourism management, v. 33, n. 2, pp. 387-396.

https://doi.org/10.1016/j.tourman.2011.04.008

Kim, Sangkyun; Assaker, Guy (2014). "An empirical examination of the antecedents of film tourism experience: a structural model approach". Journal of travel \& tourism marketing, v. 31, n. 2, pp. 251-268.

https://doi.org/10.1080/10548408.2014.873316

Kim, Sangkyun; Long, Philip (2012). "Touring TV soap operas: genre in film tourism research". Tourist studies, v. 12, n. 2, pp. 173-185.

https://doi.org/10.1177/1468797612449249

Kim, Sangkyun; Long, Philip; Robinson, Mike (2009). "Small screen, big tourism: the role of popular Korean television dramas in south Korean tourism". Tourism geographies, v. 11, n. 3, pp. 308-333.

https://doi.org/10.1080/14616680903053334

Kim, Seongseop; Kim, Sangkyun (2018). "Perceived values of TV drama, audience involvement, and behavioral intention in film tourism". Journal of travel \& tourism marketing, v. 35, n. 3, pp. 259-272.

https://doi.org/10.1080/10548408.2016.1245172

Leotta, Alfio (2009). "Framing the beach: a tourist reading of The Piano". Studies in Australasian cinema, v. 3, n. 3, pp. 229-238.

https://doi.org/10.1386/sac.3.3.229_1

Leotta, Alfio (2020). "Naples for urban voy(ag)eurs: tourism and the representation of space in Gomorrah and My BriIliant Friend". Journal of Italian cinema \& media studies, v. 8, n. 2, pp. 205-219.

https://doi.org/10.1386/jicms_00017_1

López, Lucrezia; Santomil-Mosquera, David; Lois-González, Rubén-Camilo (2015). "Film-induced tourism in the Way of Saint James". Almatourism. Journal of tourism culture and territorial development, v. 6, n 4, pp. 18-34.

https://doi.org/10.6092/issn.2036-5195/4951 
Luo, Danling; Lin, Haowen; Li, Zhou; Liu, Yong (2014). "A kiss for three decades: Comparative researches on film language and tourism destination image between two versions of 'Romance on Lushan Mountain'”. Asian social science, v. 10, n. 19 , pp. 240-257.

https://doi.org/10.5539/ass.v10n19p240

Macionis, Niki (2004). "Understanding the film-induced tourist". In: Frost, Warwick; Croy, W. Glen; Beeton, Sue. International tourism and media conference proceedings. Melbourne: Tourism Research Unit, Monash University, pp. 86-97. ISBN: 9780975713105

Macionis, Niki; Sparks, Beverley (2009). “Film-induced tourism: an incidental experience. Tourism Review International". Tourism review international, v. 13, n. 2, pp. 93-102.

https://doi.org/10.3727/154427209789604598

Marine-Roig, Estela (2011a). "Innovation and identity in Barcelona's tourist image as represented by souvenirs". Catalan journal of communication \& cultural studies, v. 3, n. 2, pp. 175-193.

https://doi.org/10.1386/cjcs.3.2.175_1

Marine-Roig, Estela (2011b). "The image and identity of the Catalan coast as a tourist destination in twentieth-century tourist guidebooks". Journal of tourism and cultural change, v. 9, n. 2, pp. 118-139.

https://doi.org/10.1080/14766825.2011.566929

Mercille, Julien (2005). "Media effects on image". Annals of tourism research, v. 32, n. 4, pp. 1039-1055.

https://doi.org/10.1016/j.annals.2005.02.001

Mestre, Rosanna; Del-Rey, Antonia; Stanishevski, Konstantin (2008). "The image of Spain as tourist destination built through fictional cinema". Journal of travel \& tourism marketing, v. 24, n. 2-3, pp. 185-194.

https://doi.org/10.1080/10548400802092718

Michael, Noela; Balasubramanian, Sreejith; Michael, Ian; Fotiadis, Anestis (2020). "Underlying motivating factors for movie-induced tourism among Emiratis and Indian expatriates in the United Arab Emirates". Tourism and hospitality research, v. 20, n. 4, pp. 435-449.

https://doi.org/10.1177/1467358420914355

Miossec, Jean-Marie (1977). "L'image touristique comme introduction à la géographie du tourisme". Annales de géographie, n. 473, pp. 55-70.

https://www.persee.fr/doc/geo_0003-4010_1977_num_86_473_17568

Monaco, James (2000). How to read a film: movies, media, multimedia. London: Oxford University Press. ISBN: 019 $513981 X$

Nanjangud, Apoorva; Reijnders, Stijn (2020). “Cinematic itineraries and identities: studying Bollywood tourism among the Hindustanis in the Netherlands". European journal of cultural studies, online first.

https://doi.org/10.1177/1367549420951577

Navarrete, Luis (2009). Historia de un género cinematográfico: la españolada. Madrid: Quiasmo. ISBN: 97884937500 60

Nieto-Ferrando, Jorge (2020). "Tourist destination placement in fiction films: an applied research proposal". Communication \& society, v. 33, n. 4, pp. 1-17.

https://doi.org/10.15581/003.33.4.1-17

Nieto-Ferrando, Jorge; Marine-Roig, Estela; Ferrer-Rosell, Berta; Martín-Fuentes, Eva (2021). "La imagen turística de Barcelona en la ficción audiovisual. Catalanidad, cosmopolitismo y mediterraneidad versus españolada". EURE. Revista latinoamericana de estudios urbano regionales (en prensa).

https://www.researchgate.net/publication/353587590_La_imagen_turistica_de_Barcelona_en_la_ficcion_ audiovisual_Catalanidad_cosmopolitismo_y_mediterraneidad_versus_espanolada

O'Connor, Noelle; Flanagan, Sheila; Gilbert, D. David (2008). "The integration of film-induced tourism and destination branding in Yorkshire, UK". International journal of tourism research, v. 10, n. 5, pp. 423-437.

https://doi.org/10.1002/jtr.676

Oviedo-García, M. Ángeles; Castellanos-Verdugo, Mario; Trujillo-García, M. Antonia; Mallya, Thaddeus (2016). "Film-induced tourist motivations. The case of Seville (Spain)". Current issues in tourism, v. 19, n. 7, pp. 713-733. https://doi.org/10.1080/13683500.2013.872606

Ozretic-Dosen, Durdana; Previsic, Jozo; Krupka, Zora; Skare, Vatroslav; Komarac, Tanja (2018). "The role of familiarity in the assessment of Turkey's country/destination image: going beyond soap operas". International journal of culture, tourism and hospitality research, v. 12, n. 3, pp. 277-291.

https://doi.org/10.1108/IJCTHR-06-2017-0066 
Quintal, Vanessa; Phau, lan (2015). "The role of movie images and its impact on destination choice". Tourism review, v. 70, n. 2, pp. 97-115.

https://doi.org/10.1108/TR-03-2014-0009

Pan, Steven; Tsang, Nelson (2014). "Inducible or not - A telltale from two movies". Journal of travel \& tourism marketing, v. 31, n. 3, pp. 397-416.

https://www.doi.org/10.1080/10548408.2014.883345

Peters, Mike; Schuckert, Markus; Chon, Kaye; Schatzmann, Clarissa (2011). "Empire and romance: movie-induced tourism and the case of the Sissi movies". Tourism recreation research, v. 36, n. 2, pp. 169-180.

https://doi.org/10.1080/02508281.2011.11081317

Poutet, Hervé (1995). Images touristiques de l'Espagne: de la propagande politique à la promotion touristique. Paris: Harmattan. ISBN: 2738430309

Pratt, Stephen (2015). “The Borat effect: film-induced tourism gone wrong". Tourism economics, v. 21, n. 5, pp. $977-993$. https://doi.org/10.5367/te.2014.0394

Prieto-Arranz, José I.; Casey, Mark E. (2014). "The British working class on holiday: a critical reading of ITV's Benidorm”. Journal of tourism and cultural change, v. 12, n. 1, pp. 68-83.

https://doi.org/10.1080/14766825.2013.877472

Privitera, Donatella (2015). "Film and the representation of the poverty. Touristic mobilities in developing countries". Almatourism. Journal of tourism culture and territorial development, v. 6, n. 4, pp. 269-281.

https://doi.org/10.6092/issn.2036-5195/4966

Redondo, Ignacio (2012). "Assessing the appropriateness of movies as vehicles for promoting tourist destinations". Journal of travel \& tourism marketing, v. 29, pp. 714-729.

https://doi.org/10.1080/10548408.2012.720156

Reijnders, Stijn (2009). "Watching the detectives. Inside the guilty landscapes of inspector Morse, Baantjer and Wallander". European journal of communication, v. 24, n. 2, pp. 165-181.

https://doi.org/10.1177/0267323108101830

Reijnders, Stijn (2016). "Stories that move: fiction, imagination, tourism". European journal of cultural studies, v. 19, n. 6, pp. $672-689$. https://doi.org/10.1177/1367549415597922

Rein, Irving; Kotler, Philip; Haider, Donald H. (1993). Marketing places: attracting investment, industry, and tourism to cities, states, and nations. New York: The Free Press. ISBN: 9780743236362

Richards, Greg (2007). "Tourism and identity in Catalunya”. In: Richards, Greg; Pereiro-Pérez, Xerardo (eds.). Cultural tourism: negotiating identities. Vila Real-Chaves: Universidade de Trás-os-Montes e Alto Douro, pp. 1-4. ISBN: 9789726698302

Riley, Roger; Baker, Dwayne; Van-Doren, Carlton S. (1998). “Movie induced tourism”. Annals of tourism research, v. 25, n. 4, pp. 919-935.

https://doi.org/10.1016/S0160-7383(98)00045-0

Riley, Roger; Van-Doren, Carlton S. (1992). "Movies as tourism promotion: a pull factor in a push location". Tourism management, v. 13, n. 3, pp. 267-74.

https://doi.org/10.1016/0261-5177(92)90098-R

Rodríguez-Campo, Lorena; Fraiz-Brea, José-Antonio; Rodríguez-Toubes-Muñiz, Diego (2011). "Tourist destination image formed by the cinema: Barcelona positioning through the feature film Vicky Cristina Barcelona". European journal of tourism, hospitality and recreation, v. 2, n. 1, pp. 137-154.

http://hdl.handle.net/10400.8/447

Roesch, Stefan (2009). The experiences of film location tourists. Bristol Channel View. ISBN: 9781845411206 https://doi.org/10.21832/9781845411220

Rose, Guillian (2001). Visual methodologies: an introduction to researching with visual materials. Londres: SAGE. ISBN: 07619665 X

Said, Edward (1979). Orientalism. New York: Vintage Books. ISBN: 9780394740676

Sánchez-Castillo, Sebastián (2020). "Research on film as an inducer of tourism: a methodological review". L'Atalante, n. 30, pp. 109-122.

http://www.revistaatalante.com/index.php?journal=atalante \&page=article \&op=view \&path\%5B\%5D=815

Sánchez-Castillo, Sebastián (2021). "Estímulo del turismo a través de la ficción audiovisual. Métodos de investigación". En: Nieto-Ferrando, Jorge; Del-Rey, Antonia; Martín-Fuentes, Eva (eds.). Turismo inducido por el audiovisual. Revisión metodológica y propuestas de investigación transdisciplinar. Salamanca: Comunicación Social, pp. 25-47. ISBN: 9788417600464 
Sánchez-Escalonilla, Antonio (2014). Estrategias de guión cinematográfico: el proceso de creación de una historia. Barcelona: Ariel. ISBN: 9788434414945

Shani, Amir; Wang, Youcheng; Hudson, Simon; Moreno-Gil, Sergio (2009). "Impacts of a historical film on the destination image of South America". Journal of vacation marketing, v. 15, n. 3, pp. 229-242.

https://doi.org/10.1177/1356766709104269

Smith, Andrew (2005). "Conceptualizing city image change: the 're-imaging' of Barcelona". Tourism geographies, v. 7, n. 4, pp. 398-423.

https://doi.org/10.1080/14616680500291188

Smith, Andrew (2007). "Monumentality in 'capital' cities and its implications for tourism marketing". Journal of travel \& tourism marketing, v. 22, n. 3-4, pp. 79-93.

https://doi.org/10.1300/J073v22n03_07

Soliman, Dalia-Mohammad (2011). "Exploring the role of film in promoting domestic tourism: a case study of AL Fayoum, Egypt". Journal of vacation marketing, v. 17, n. 3, pp. 225-235.

https://doi.org/10.1177/1356766711409183

Spears, Daniel L.; Josiam, Bharath M.; Kinley, Tammy R.; Pookulangara, Sanjukta (2013). "Tourist see tourist do: the influence of Hollywood movies and television on tourism motivation and activity behavior". FIU hospitality review, v. 30 , n. 1, pp. 54-75.

https://digitalcommons.fiu.edu/hospitalityreview/vol30/iss1/4

St-James, Yannik; Darveau, Jessica; Fortin, Josyane (2018). “Immersion in film tourist experiences”. Journal of travel \& tourism marketing, v. 35, n. 3, pp. 273-284.

https://doi.org/10.1080/10548408.2017.1326362

Su, Hung-Jen; Huang, Yu-An; Brodowsky, Glen; Kim, Hyun-Jeong (2011). "The impact of product placement on TV-induced tourism: Korean TV dramas and Taiwanese viewers". Tourism management, v. 32, n. 4, pp. 805-814.

https://doi.org/10.1016/j.tourman.2010.06.020

Suhud, Usep; Willson, Gregory B. (2018). "The image of India as a travel destination and the attitude of viewers towards Indian TV dramas". African journal of hospitality, tourism and leisure, v. 7, n. 3, pp. 1-13.

https://www.ajhtl.com/uploads/7/1/6/3/7163688/article_11_vol773_2018.pdf

Tooke, Nichola; Baker, Michael (1996). "Seeing is believing: The effect of film on visitor numbers to screened locations". Tourism management, v. 17, n. 2, pp. 87-94.

Tzanelli, Rodanthi (2003). "'Casting' the Neohellenic 'other': Tourism, the culture industry, and contemporary Orientalism in 'Captain Corelli's Mandolin”. Journal of consumer culture, v. 3, n. 2, pp. 217-244.

https://doi.org/10.1177/14695405030032004

Urso, Giulia (2015). "Salento atmosphere and the role of movies". Almatourism. Journal of tourism, culture and territorial development, v. 6, n. 4, pp. 229-240.

https://doi.org/10.6092/issn.2036-5195/4963

Vale, Eugene (1996): Técnicas del guión para cine y televisión. Gedisa: Barcelona. ISBN: 9788474322231

Vanoye, Francis (1996). Guiones modelo y modelos de guión. Argumentos clásicos y modernos en el cine. Barcelona: Paidós. ISBN: 9788449302077

Wen, Han; Josiam, Bharath M.; Spears, Daniel L.; Yang, Yi (2018). “Influence of movies and television on Chinese tourists perception toward international tourism destinations". Tourism management perspectives, v. 28, pp. $211-219$. https://doi.org/10.1016/j.tmp.2018.09.006

Yang, Fang; Vanden-Bergh, Bruce; Lee, Joonghwa (2017). “Do violent movies scare away potential visitors?”. International journal of advertising, v. 36, n. 2, pp. 314-335.

https://doi.org/10.1080/02650487.2015.1101224

Zamorano, Mariano-Martín (2020). “El modelo emprendedor de políticas culturales y el destination branding. Un análisis a partir del filme Vicky Cristina Barcelona". EURE. Revista latinoamericana de estudios urbano regionales, v. 46, n. 139, pp. 91-112.

https://doi.org/10.4067/S0250-71612020000300091

Zeng, Shiheng; Chiu, Weisheng; Lee, Chul-Won; Kang, Hyun-Wook; Park, Chanmin (2015). "South Korea's destination image: comparing perceptions of film and nonfilm Chinese tourists". Social behavior and personality: an international journal, v. 43, n. 9, pp. 1453-1462.

https://doi.org/10.2224/sbp.2015.43.9.1453 